\title{
@ccreative
}

BY-NC-SA 4.0

UMÁTICA. Revista sobre Creación y Análisis de la Imagen

\{ISSN: 2659-5354// D.L.: MA- 1628-2018\}

\section{El sueño atávico de la muñeca:}

\section{Más allá del discurso canónico sobre las imágenes*}

The Doll's Atavistic Dream: Beyond the canonical theory of images

DOROTA Mạ KURAŻYŃSKA

JUAN J. CABRERA

Universidad de Granada

\section{Resumen}

Este trabajo versa sobre teoría de las imágenes y su objeto de estudio es la muñeca. Pretendemos llamar la atención sobre algunas de las razones del impasse en el que se encuentra la teoría de las imágenes y sugerir una vía para sortearlo. Como estudio de caso hemos seleccionado un ensayo de Maurizio Bettini titulado "Pupa. La muñeca en la cultura griega y romana", que analizaremos con cierto detalle porque evidencia algunas de las paradojas y aporías involucradas por la doctrina canónica de la imagen — que postula que imagen = signo. En vez de examinar la abrumadora cantidad de autores que han encarado la cuestión "¿qué es una imagen?", nos centraremos en dos eruditos prominentes: J. W. T. Mitchell y Ernst H. Gombrich. El primero porque representa lúcida y brillantemente el discurso convencionalista de la doctrina canónica de la imagen. El segundo por ser el principal y más clarividente portavoz de un enfoque multilateral no reduccionista que permite atender y explicar usos no semióticos de las imágenes. Aceptando que "el significado de una palabra es su uso en el lenguaje", asumiremos que imagen es todo aquello de lo cual se dice que es una imagen, aunque nuestro estudio trata únicamente de imágenes que son artefactos físicos

Artículo original Original Article

Correspondencia

Correspondence

Juan J. Cabrera

jcabrera@ugr.es

Financiación

Fundings

Sin financiación

Received: 02.12.2018

Accepted: 22.12.2018

PALABRAS CLAVE: imagen, usos de las imágenes, muñeca, robot, artefacto-útil, technical artifacts,

CÓMO CITAR ESTE TRABAJO / HOW TO CITE THIS PAPER

Kurażyńska, D y Cabrera, J. (2018). El sueño atávico de la muñeca: Más allá del discurso canónico sobre las imágenes. Umática. Revista sobre Creación y Análisis de la Imagen , 1: 57-104.

http://dx.doi.org/10.24310/Umatica.2018.voi1.5355

Umática. 2018; 1: 57-104 


\title{
The Doll's Atavistic Dream: Beyond the canonical theory of images
}

\section{DOROTA Mạ KURAŻYŃSKA \& JUAN J. CABRERA}

Universidad de Granada

\begin{abstract}
:
This paper deals with the theory of images and its object of study is the doll. We intend to draw attention to some of the reasons for the impasse on which Image Theory is based and suggest a way to avoid it. As a case study we have selected an essay by Maurizio Bettini entitled "Pupa. La bambola nella cultura greca e romana" ["Pupa. The doll in Greek and Roman culture"]. We will analyze it in some detail, because it evidences some of the paradoxes and aporias involved by the canonical doctrine of images - which postulates that image = sign. Instead of trying to survey the overwhelming number of authors who have addressed the question "what is an image?", we have chosen to concentrate here on two prominent figures: J. W. T. Mitchell y Ernst H. Gombrich. The first one, because brilliant and lucidly represents the conventionalist discourse of the canonical doctrine of images. The second, because is widely recognized as the main and most farsighted speaker of a non-reductionist multilateral approach that allows us to attend and explain non-semiotic uses of the images. Accepting that "the meaning of a word is its use in language", we will assume that image is everything that is said to be an image, although our study deals only with images which are physical artifacts.
\end{abstract}

KEYWORDS: image, uses of the images, doll, robot, artifact-tool, technical artifacts

Summary - Sumario:

(*) Este trabajo es una ampliación del texto preparado conjuntamente con Dorota María Kurażyńska para la ponencia "Muñecas:

Sueños \& juegos ancestralese imágenes de nueva generación para la próxima generación", presentada en: III Encontro de Cultura Visual el 6 de diciembre de 2018 en la Universidade Lusófona do Porto. Este
$\S$ 1. Presentación

$\S$ 2. Maurizio Bettini: Lo que una muñeca es

$\S$ 2.1. La muñeca de Crepereia Tryphaena

$\S$ 2.2.1. Escena primera: El juego privado de la joven con su muñeca

$\S$ 2.2. Maurizio Bettini: "Pupa. La muñeca en la cultura griega y romana"

$\S$ 2.2.2. Interludio

§ 2.2.2.1. Excurso: Una estatua no se usa como una muñeca

$\S$ 2.2.2.1.a. Estatuas vs. muñecas, humanitas vs. barbaritas $\&$ feritas

§ 2.2.2.2. La irrupción de hombres con toda la barba

$\S$ 2.2.3. Escena segunda: El juego público de la sociedad con la muñeca

$\S$ 2.2.4. Conclusión: La muñeca es una imagen que significa virginidad

$\S$ 3. Las imágenes no existen

$\S$ 4. W. J. T. Mitchell: patos \& inágenes de pato tatusas-pato

$\S 5$. Ernst H.Gombrich: ¿Tiene que ser siempre cierto que una imagen es una representación?

$\S$ 5.1. Muñeca de Crepereia = ser que pertenece a la especie mujer, subespecie mujer de marfil

§6. El sueño atávico de la muñeca haciéndose realidad

$\S 6.1$. "What Do You Mean, 'It's Just Like a Real Dog'?

$\S 7$. Desenlace: "Dream dolls became physical reality""

$\S 8$. Conclusiones: 


\section{$\S$ 1. Presentación}

Han pasado más de 60 años desde que René Huyghe, angustiado por la creciente influencia de los mass media en el comportamiento de la gente, afirmó que la "civilisation du livre" estaba siendo rebasada por la "civilisation de l'image" (Dialogue avec le visible, 1955). Esta misma "ansiedad" aparece reflejada en las primeras páginas de la Picture Theory (Teoría de la imagen, 2009) publicada en 1994 por Mitchell.

Hace décadas que se dice que hemos ingresado en la Era de las imágenes, y parece evidente que vivimos en un mundo donde la relevancia de las imágenes parece cada vez mayor. Se ha dicho que "el problema del siglo XXI es el problema de la imagen" (Mitchell, 2009: 10). Las imágenes importan y, puesto que importan, el conocimiento sobre las imágenes debe ser importante y deberíamos disponer de un conocimiento solvente acerca de ellas. Pero cuando revisamos la literatura sobre el tema, comprobamos que los expertos que se muestran insatisfechos ante el estado del conocimiento sobre las imágenes son muchos. Aportaremos un único ejemplo: "Aunque tenemos miles de palabras sobre las imágenes", se lamenta Mitchell, "aún no poseemos una teoría satisfactoria sobre ellas. [...] Quizá el problema no esté sólo en las imágenes, sino en la teoría." (:17)

Este descontento se hace patente en llamamientos como el de James Elkins, que denunciando la arbitrariedad de los criterios utilizados en sus estudios por los historiadores para la selección de imágenes, ha urgido a prestar atención a la amplia gama de imágenes "no artísticas" tradicionalmente ignorada por la Historia del Arte ${ }^{1}$. La crítica podría hacerse extensiva al conjunto de los estudios sobre imágenes. De hecho, y a pesar de la emergencia del Pictorial Turn y del auge internacional de la Visual Culture, la doctrina canónica de la imagen, además de no haberse zafado de la confusión del discurso sobre las imágenes con el discurso sobre el Arte, adolece de una debilidad crucial: asumiendo que las imágenes son una modalidad de signos, se muestra incapaz de ofrecer una definición plausible de "imagen" y, por tanto, inhabilitada para conformar un conocimiento sólidamente fundamentado de las imágenes.

Llamamos "teoría" o "doctrina canónica de la imagen" a la concepción de las imágenes que las reduce a la condición de signos y afirma que "imagen = signo". Mitchell da cuenta de ella en su ensayo "¿Qué es una imagen?" indicando:

El tópico de los actuales estudios sobre las imágenes establece que han de ser entendidas como una forma de lenguaje; en vez de como una ventana transparente al mundo, las imágenes se consideran en la actualidad como un tipo de signo que presenta una apariencia engañosa de naturalidad y transparen-

1. Elkins, 2001: 3 y ss. En la Teoría de la imagen de Mitchell encontramos un alegato semejante: "Ahora que la historia del arte despierta, o por lo menos ha despertado al giro lingüístico, ¿qué es lo que hará? Las alternativas son predecibles y las revistas académicas ya están llenas de ellas, se descubre que las artes visuales son 'sistemas de signos', formados por 'convenciones', que los cuadros, las fotografías, los objetos escultóricos y los monumentos arquitectónicos están llenos de 'textualidad' y 'discurso'. [...] Ocuparse de las obras maestras de la pintura occidental, claramente, no será suficiente." (Mitchell, 2009: 141)

Umática. 2018; 1: 57-104 
cia, y que oculta un mecanismo de representación opaco, tergiversador y arbitrario, un proceso de mistificación ideológica. (Mitchell, 2011: 108-109)

Si hay un evangelio "canónico" de las imágenes, también debe haber otro "apócrifo". En el pasaje anterior de Mitchell se insinúa cuál es: el descalificado como mistificación ideológica por postular la posibilidad de que entre algunas imágenes y las cosas del mundo con las cuales las relacionamos pueda existir un vínculo de naturalidad no tergiversadora y arbitraria. Aunque Mitchell no lo menciona aquí, para él, el principal apóstol del evangelio apócrifo de las imágenes es Gombrich.

Una de las dificultades de la teoría canónica de la imagen es que no puede aportar una definición solvente del término "imagen". Asumiendo la petitio principii que estipula que imagen = signo y, por tanto, que la relación entre las imágenes y las cosas a las que son vinculadas es siempre y necesariamente tan convencional y arbitraria como el vínculo de las palabras con lo denotado por éstas, el hiato que distingue las imágenes de las palabras se emborrona². Así que, aunque se asegura con rotundidad que el género próximo de las imágenes es "signo", no hay forma de establecer cuál es la diferencia específica que distingue a las

2. Aquí la con-fusión de las imágenes con las palabras derivada de este emborronamiento es aducida como un fallo impropio de un discurso riguroso que aspire a clarificar y mejorar nuestra comprensión de las imágenes. No obstante, esta con-fusión es saludada como un progreso en el desvelamiento de la verdadera naturaleza de las imágenes por los representantes de la doctrina canónica de la imagen. Por ejemplo, la reseña aportada por el editor de Iconology: Image, Text, Ideology para promocionar este trabajo de Mitchell es el siguiente pasaje de la crítica a este libro de Rudolf Arnheim: "[Mitchell] undertakes to explore the nature of images by comparing them with words, or, more precisely, by looking at them from the viewpoint of verbal language. [...]. The most lucid exposition of the subject I have ever read" (https://books.google.es/books/about/lconology.html?id=sQmqAAAAQBAJEtredir_esc=y). En la Introducción a su Teoría de la imagen, Mitchell explica el sentido de su libro diciendo: "Básicamente, se trata de una secuela y de un volumen que acompaña a otro libro, Iconology, que publiqué en 1986. En lconology me preguntaba cómo son las imágenes, en qué se diferencian de las palabras y por qué es importante siquiera plantearse estas preguntas. Teoría de la imagen plantea estas mismas preguntas respeto de los objetos representacionales concretos en los que aparecen las imágenes*. Se pregunta qué es una imagen y encuentra que no se puede responder a esta pregunta sin una reflexión extensa sobre los textos, sobre todo la forma en que los textos actúan como imágenes o "incorporan" la práctica pictórica y viceversa. [...] Una afirmación polémica de Teoría de la imagen es que esta interacción entre imágenes y textos es constitutiva de la representación en sí: todos los medios son medios mixtos y todas las representaciones son heterogéneas; no existen las artes "puramente" visuales o verbales." Más adelante, Mitchell declara "La idea de que las imágenes pueden leerse como textos no se puede considerar nueva en la historia del arte: es lo que toca aprenderse, el último grito" y, también, "Por ejemplo, la distinción de Goodman entre imágenes y textos como, respectivamente, un sistema denso y otro diferenciado, nos da un respiro clarificador, frente a las distinciones metafísicas como las basadas en el espacio y el tiempo o la naturaleza y la convención. Las diferencias entre los tipos de símbolos se convierten en algo relativo que tiene que ver con cuestiones de función, de contexto y de hábito, y dejan de ser una cuestión de esencias o de categorías absolutas" (Mitchell, 2009: 12, 92, 299).

* Con la expresión "objetos representacionales concretos en los que aparecen las imágenes" Mitchell se refiere a lo que él denomina "pictures", que distingue de lo que él llama "images" - con esta palabra se remite a una entidad inmaterial, a una visión mental, a una idea que puede "encarnarse" en un objeto físico ("picture"), que sería una representación de dicha idea. 
imágenes de los signos alfabéticos o numéricos. Por eso la teoría canónica de la imagen es incapaz de contestar la pregunta "¿Qué no es una imagen?"з

Este trabajo no pretende resolver la pregunta "¿qué es una imagen?" Su objetivo tiene un alcance más modesto: hacer patentes algunas de las dificultades del discurso canónico sobre las imágenes para afrontar la pregunta "¿qué tipo de imagen es una muñeca?" Antes que de imágenes sublimes como la Victoria de Samotracia, las Venus de Botticelli o La Grande Odalisque de Ingres, aquí se hablará de imágenes bastante más cotidianas y modestas: la inscripción $\vee$, la prótesis dental, el avión de papel y, sobre todo, la muñeca — ese juguete que solemos asociar con niñas que tantos y tan atávicos sueños "pigmaliónicos" ha suscitado en hombres. En Simulacros. El efecto Pigmalión, Victor I. Stoichita aborda el tema de la imagen tratando cuestiones coincidentes con las tratadas aquí, aunque opta por "ignorar todo un abanico de aspectos actualmente candentes y peligrosamente vertiginosos"; él "no quiere penetrar en la sociedad de simulacros y sus engaños" (Stoichita, 2006: 17). Aquí se hablará de imágenes antiguas como la mujer de marfil de Pigmalión y de una muñeca romana del siglo II, pero también de esas imágenes — dotadas de una actualidad vertiginosamente candente- que son las muñecas robóticas.

Actualmente, la respuesta habitual a la pregunta "¿qué es una imagen?" suele ser: "es una representación de una persona o una cosa", es decir, algo que existe para hacer pensar en algo distinto de eso que está ahí. Estamos tan familiarizados con esta idea que nos cuesta pensar las imágenes de otro modo, y, como "la observación depende de la teoría" —porque "la teoría guía la observación y la experimentación" “—, no sólo observamos y experimentamos esto cuando nos encontramos con una imagen, sino que esto es lo que vemos en todo aquello que ha sido etiquetado con el rótulo "imagen". Aquí se argumentará contra la identificación imagen = representación .

En nuestra vida cotidiana, la interacción con imágenes es continua, y la palabra "imagen" aparece a regularmente en nuestras conversaciones. La empleamos sin titubear, como si denotara algo tan claro como lo referido por palabras como "rana", "oro" o "telescopio". Con esta misma desenvoltura es empleada en los medios de comunicación, donde compadece a diario como un personaje habitual. Pero la palabra "imagen" también se ha vuelto popular en el ámbito universitario y, aquí, lo denotado por el término "imagen" ha dejado de darse (tan ingenuamente) por descontado y ha pasado a verse como un enrarecido campo de poderosas vaguedades, entrecruzamientos cognoscitivos inextricables y, sobre todo, confrontaciones ideológicas.

3. Esta pregunta fue formulada por uno de los participantes (Steffen Siegel) en el Seminario "What is an Image?", organizado en 2010 por Elkins. Ninguno de los asistentes (incluído Mitchell) fue capaz de ofrecer una respuesta plausible a esta cuestión (Elkins, 2010:235 ss.). La versión original en Elkins, James \&t Naef, Maja (ed.) 2011: 14 y ss.

4. La idea de que la observación es precedida y guiada por la teoría es una de las aportaciones notables de la crítica de Karl Popper al método inductivo. Aparece recogida en Conjeturas y refutaciones (Popper, 1991: 72). Alan F. Chalmers dedica a esta cuestión el tercer capítulo de ¿Qué es esa cosa llamada ciencia?, cuyo título es "La observación depende de la teoría" (Chalmers, 1991).

Umática. 2018; 1: 57-104 
Desde hace unas décadas, y cada vez más, el término "imagen" está siendo objeto de una atención específica y sostenida por parte de la erudición universitaria. Esta atención se concreta en una infinidad creciente de trabajos donde la palabra "imagen" es estudiada y cultivada como un espécimen pasmoso de planta exótica5. En efecto, la palabra "imagen" está siendo manejada en el ámbito universitario como un mecanismo complejo cuyos funcionamientos se resisten a ser dilucidados. Entre las razones que dificultan la comprensión de los empleos asignados a esta palabra, una de las más notables es la extraordinaria disparidad de objetos y fenómenos que permite nombrar (objetos tangibles — como las estatuas-, intangibles - como las ideas - e híbridos - como los cuadros-; fenómenos ópticos —como los reflejos especulares - psíquicos - como las visualizaciones mentales o los parecidosy sociológicos - como el conjunto de rasgos que caracterizan ante la sociedad a una persona o entidad; y también ciertas figuras retóricas). Es por esto que, a fecha de hoy, responder la pregunta ¿Qué es una imagen? parece una misión imposible ${ }^{6}$.

Otra dificultad que enturbia el acceso a una dilucidación cabal de lo referido con el término "imagen" resulta del divorcio entre los empleos fácticos asignados cotidianamente a las imágenes y los intereses de la erudición académica (producida principalmente en el seno de departamentos universitarios dedicados a la historiografía del Arte o la crítica literaria y esto entraña compromisos y sesgos epistemológicos que afectan al modo en que las imágenes tenidas en cuenta son seleccionadas y tomadas en consideración). Ignorando muchos de dichos empleos, o despreciándolos por "patológicos", "primitivos", "innobles", etc.?, y valiéndose de una selección asombrosamente discrecional de casos, el discurso académico pretende conformar (pars pro toto) una teoría de las imágenes que, en cierto sentido, sería algo así como una Zoología que únicamente se ocupara de los animales de granja. Una excepción a esto es el ensayo de Bettini utilizado aquí como estudio de caso.

Este trabajo está estructurado en tres partes. La primera (\$2) aporta un estudio de caso que permite ilustrar algunas de las dificultades de la teoría canónica de la imagen, que asume la fórmula imagen = signo. La segunda $(\S 3-\S 5)$ ofrece una visión de esta teoría - tomando a Mitchell como referencia-, la crítica y —ahora tomando a Gombrich como referencia - esboza un modelo alternativo de teoría. La tercera (\$ 6) echa un vistazo a algunos desarrollos actuales del atávico sueño de la muñeca viviente, contrastándolos con modali-

5. Considerando el cariz de algunos análisis, se diría que el estudio de este espécimen terminológico es afrontado como una suerte lingüística de ese clásico de la farmacopea tradicional conocido como "hierba de las brujas" que es la belladona (y que sigue siendo objeto de creencias, leyendas y fábulas diversas). De hecho, con la palabra "imagen" sucede algo semejante a lo que ocurre con esta planta mítica: es vista como una especie de hierba semántica tan tentadoramente golosa y fascinante como tóxica y señalada por su pasado. Decimos esto porque una parte en absoluto desdeñable del discurso actual sobre las imágenes es declaradamente iconofóbico, y esto compromete la posibilidad de acceder a un conocimiento riguroso de las imágenes, que debe ser un conocimiento construido sine ira et studio.

6. Vid. "¿Qué es una imagen?" (Mitchell, 2011) y, en particular, el apartado "Familia de las imágenes".

7. Véase, por ejemplo, cómo justifica Román Gubern el título de su libro Patologías de la imagen (2004), o la Introducción de David Freedberg a El poder de las imágenes. Estudios sobre la historia y la teoría de la respuesta (1992). 
dades de imágenes como la inscripción $\$, e insistiendo en las limitaciones de la teoría canónica de la imagen. El trabajo finaliza con una sección de conclusiones donde se subrayan algunas dificultades —especialmente de índole ideológica — inherentes a la doctrina canó-

nica de la imagen, y se argumenta la necesidad de recurrir a un nuevo "paradigma" que permita el acceso a un conocimiento científico (y no doctrinario) de las imágenes.

\section{$\S$ 2. Maurizio Bettini: Lo que una muñeca es}

\section{§ 2.1. La muñeca de Crepereia Tryphaena}

Como sucede tan frecuentemente en Roma, el día 10 de mayo de 1889 tuvo lugar un hallazgo excepcional. Operarios que trabajaban en las labores de excavación previas a la cimentación del futuro Palacio de Justicia encontraron dos sarcófagos antiguos de mármol. Las inscripciones indicaban que uno contenía los restos de una mujer llamada Crepereia Tryphaena y el otro los de un familiar llamado Crepereius Euhodus. Ambos vivieron a mediados del siglo Il d.C. Las tumbas estaban selladas, así que su contenido permanecía intacto.

Dos días más tarde, el arqueólogo que se hizo cargo del descubrimiento decidió abrir allí mismo los sarcófagos. El terreno aluvial en el que habían sido hallados estaba situado a orillas del Tíber y el agua del río había anegado las tumbas, así que pensó que desplazarlas a un lugar menos inconveniente entrañaba el riesgo de que su contenido fuera desordenado y dañado por los movimientos del agua.

El contenido del sarcófago de la mujer atrapó la atención de inmediato. Al retirar su tapa, lo primero que el arqueólogo, sus asistentes y la multitud agolpada en torno al hallazgo pudieron contemplar, "casi horrorizados", fue la larga y oscura cabellera del esqueleto de Crepereia ondeando sinuosamente en el agua cristalina acumulada dentro del sarcófago. La calavera estaba ligeramente inclinada hacia la izquierda, parecía mirar una muñeca que yacía apoyada sobre el omóplato.

La muñeca, que actualmente se exhibe en los Museos Capitolinos de Roma, es de marfil y mide de 23 centímetros. Sus amplias caderas y la turgencia de sus pechos indican que se trata de una adolescente que ha alcanzado la pubertad. Está dotada de extremidades articuladas, unidas mediante pernos que engarzan las junturas de los hombros, los codos, las caderas y las rodillas. Es un trabajo tan minucioso que los dedos de sus manos y sus pies han sido provistos de uñas. Llevaba un collar y pulseras de oro auténtico. Además poseía un ajuar propio: aparte de joyas reales, un bastoncito torneado de ámbar a modo de fusus, dos peines de marfil, un espejo de acero pulido y otros pequeños artículos de aseo.

Que la muñeca sea la imagen articulada de una mujer desnuda indica que fue diseñada para ser manipulada por las manos de su dueña. Ésta podía hacer que su pequeña adolescente de marfil (lo mismo que la legendaria muñeca de Pigmalión) adoptara diversas poses, caminara o se sentara. También podía vestirla y desvestirla, aderezarla con sus propias joyas y asearla con sus propios artículos de aseo. A diferencia de las estatuas monumentales, pero a semejanza de las personas, el cuerpo de esta muñeca puede presentarse mostrán- 
dose de forma diferente en el ámbito de la intimidad y en el ámbito de lo público, puede revelarse y ocultarse.

La historia de Crepereia Tryphaena estaba llamada a convertirse en un relato popular. Se dice que falleció la víspera de su boda y que ésta es la razón por la cual fue enterrada con su muñeca. En cualquier caso, si el descubrimiento de su tumba y su nombre se recuerdan todavía es por la muñeca de esta joven romana muerta hacía dieciséis siglos.

\section{§ 2.2. Maurizio Bettini: "Pupa. La muñeca en la cultura griega y romana"}

Desde que los restos de Crepereia Tryphaena fueron rescatados de las aguas y sacados a la luz, hace 130 años, es mucho lo que se ha escrito sobre su muñeca. El deseo de dar cuenta de la razón de ser de este sofisticado juguete de marfil, así como la voluntad comprender lo que una muñeca es, han encontrado en esta vieja adolescente artificial una poderosa fuente de inspiración. Han sido muchos los poetas, historiadores, antropólogos, filósofos, estudiosos de la cultura y semióticos que han escrito sobre ellå ${ }^{8}$. Uno de ellos es el catedrático en filología clásica y antropólogo italiano Maurizio Bettini.

En 1992 Bettini publicó un opúsculo titulado "Pupa. La bambola nella cultura greca e romana"9 donde, rememorando una vez más la historia de esta infortunada joven romana, se planteaba la pregunta "¿qué tipo de imagen es una muñeca?" Recientemente, este ensayo ha sido publicado en español, dentro de un pequeño volumen titulado Muñeca. Si la desdichada Crepereia Tryphaena y su fascinante muñeca aparecen en este trabajo, es porque deseamos comentar aquí este pequeño y bello ensayo de Bettini sobre "la más célebre muñeca antigua". Nuestro interés en este ensayo radica en que entendemos que permite ilustrar algunas de las paradojas y aporías planteadas por el modo en que la doctrina de las imágenes actualmente tenida por canónica enfoca y [no] resuelve la cuestión ¿qué es una imagen?

8. Información sobre la muñeca de Crepereia en Bettini, Maurizio (2015). El texto en inglés del informe de Rodolfo Lanciani, responsable de los trabajos arqueológicos involucrados por el descubrimiento del sarcófago de Crepereia, así como una primera interpretación de la muñeca, en Lanciani, Rodolfo A. (1892): Pagan and Christian Rome. Houghton, Mifflin and Company, Boston and New York, 1892 (en cap. "Imperial Tombs", págs. 301-302, ver págs. 168-208. Accesible en https://en.wikisource.org/wiki/Pagan_and_Christian_Rome, también en http://penelope.uchicago.edu/Thayer/E/Gazetteer/Places/Europe/Italy/Lazio/Roma/Rome/_Texts/Lanciani/ LANPAC/home.html). Para aproximaciones críticas a los usos de las muñecas en la Antigua Roma con referencias a la muñeca de Crepereia: D'Ambra, E. (2014). "Beauty and the Roman female portrait", en J. Elsner \& M. Meyer (Eds.), Art and Rhetoric in Roman Culture (pp. 155-180), Cambridge: Cambridge University Press. Edmondson, Jonathan. C. \& Keith, Alison (eds.) J. C.; Roman Dress and the Fabrics of Roman Culture, University of Toronto Press, 2008. Shumka, Leslie (2008). "Designing Women: The Representation of Women's Toiletries on Funerary Monuments in Roman Italy", en Roman dress and the fabrics of Roman culture, University of Toronto Press, 2008, pp. 172-191. Para el uso de las muñecas como juguetes en la Antigua Roma: Rawson, Beryl (2003). Children and Childhood in Roman Italy (en inglés). Oxford University Press, pág. 128, 145.

9. Bettini, Maurizio (1992): Pupa: la bambola nella cultura greca e romana. Urbino, Quattroventi (accesible en https://semiotica.uniurb.it/wp-content/uploads/2013/09/205-C.pdf). Este ensayo aparece incluido en Bettini, Maurizio (1992): Il ritratto dell'amante, Torino, Einaudi. 
Bettini despliega su exposición articulándola en dos Escenas. La primera nos sitúa en el dominio íntimo y lábil del juego privado de la joven con su juguete. Aquí, Bettini se recrea describiendo tanto las virtualidades del cuerpo de la muñeca como las del nombre dado por los romanos de la Antigüedad a este juguete: "pupa" (que significa "muñeca", "muchacha" y "pupila"). En la segunda, nos sitúa en la externalidad del ámbito público y señaladamente estereotipado del juego social con la muñeca, y es ahora cuando el autor de "Pupa" des-cubre la respuesta a la pregunta "¿qué tipo de imagen es una muñeca?" - a saber: es una imagen que funciona como un signo que denota "virginidad". Entre estas dos Escenas, el autor de "Pupa" interpola un Interludio que, provocando un vuelco crucial en el enfoque del asunto, motiva un cambio de Escena y una variación radical en la luz con la que alumbra sus pesquisas.

\section{$\S$ 2.2.1. Escena primera: El juego privado de la joven}

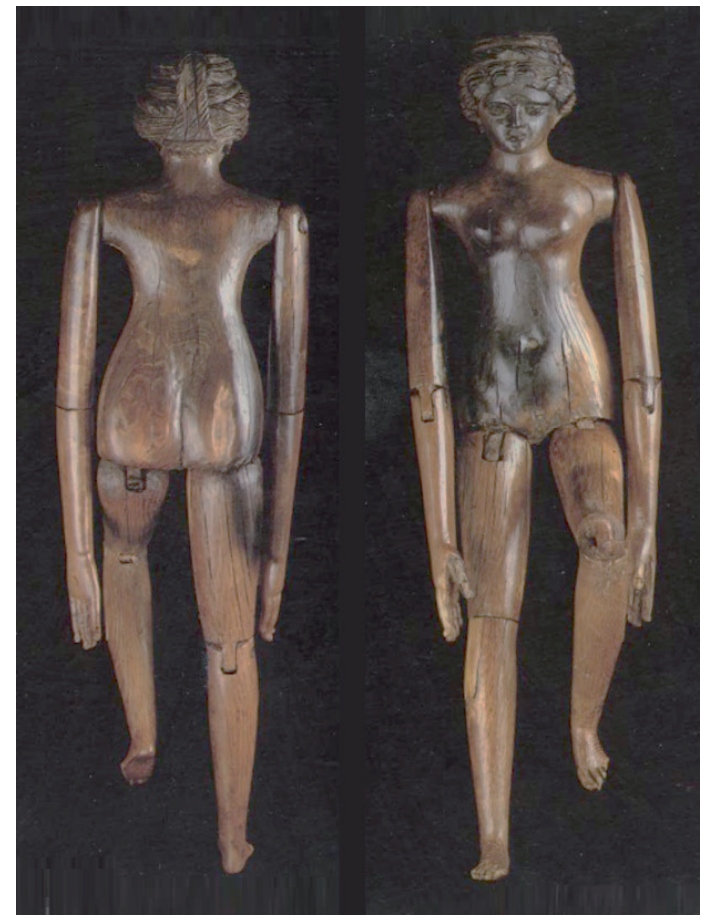
con su muñeca

La muñeca de Crepereia es descrita como la imagen minuciosamente naturalista de una pequeña joven de marfil cuyo cuerpo ha sido concebido y diseñado para ser mani-obrado físicamente. Bettini la presenta como un cuerpo al que se le hacen cosas, con el que se hacen cosas y al cual se hace hacer cosas. Conocemos otros juguetes igualmente diseñados para ser manipulados, como el cubo de Rubik o el yo-yo, que también consisten en cuerpos diseñados ex profeso para que resulten idóneos respecto del fin al que están destinados siendo manipulados físicamente. Pero, a diferencia de estos juguetes, que están destinados a capacitar habilidades intelectuales o motrices (el rompecabezas de Rubik desarrolla la memoria y la organización espacial, el yo-yo habilidades técnicas vinculadas con destrezas motrices), y que son empleados como objetos, la muñeca es un cuerpo de mujer que ha sido concebido y conformado para que sirva como compañera de juegos de su dueña, es decir, para ser visto como sujeto.

Bettini llama la atención sobre "los pequeños senos pronunciados y realzados por los pezones, el vientre apenas modelado y un complicado peinado que refleja la moda del siglo II" (22). Desea subrayar que se trata de la imagen de una "jovencita" (y no de la de un bebé) porque quiere dejar claro que este juguete no estaba destinado a juegos de "maternidad simulada" (23). Estaba destinado a servir como "una compañera de su amita [...] que participa en el juego no como sujeto infantil que demanda cuidados y protección, sino como partner de pleno derecho" (23).

En su ensayo, Bettini formula explícitamente la pregunta "¿qué tipo de imagen es la muñeca?" en dos ocasiones. La primera vez lo hace en el marco de esta Escena primera (27). Contesta desarrollando bastante detalladamente la idea de que la muñeca ha de verse Umática. 2018; 1: 57-104

Fig. 01.

Muñeca articulada hallada en el interior del sepulcro junto a su propietaria Crepereia Tryphaenas [s.ll d.C.] |cc-wikimedia commos. 
como una partner de Crepereia en sus juegos, y dando cuenta de la "condición de 'muchacha' propia de la muñeca" (23). Permítasenos citar extensamente a Bettini:

[T]odas estas características sitúan a la pupa más en el terreno del movimiento y la vida que en el de la inmutabilidad icónica. Lo mismo en lo que se refiere a los orificios que permiten el uso de pendientes, a los dedos ahusados que admiten los anillos, a los cabellos auténticos que hacen necesario un pequeño equipo de peines. La muñeca tiende en suma a proponerse como figura de persona viva, o próxima a la vida; no inmóvil simulacro de un ser animado diferente de ella [...], sino imagen/no imagen que vive en el límite del mundo del movimiento y del sonido, dispuesta a participar en él si así se desea. En cuanto tal, la muñeca admite, incluso exige, un conjunto de operaciones, se define precisamente a partir de la posibilidad de llevar pendientes y vestidos, de ser peinada, de moverse con pasos inseguros o rápidos guiada por manos infantiles. La muñeca interactúa con quien la posee; más concretamente, admite, e incluso exige, la manipulación: no se puede imaginar una muñeca, con su ajuar personal, sus muebles y utensilios domésticos, si no es como un objeto que existe para ser manipulado por los dedos de quien se entretiene con ella. (27-29)

\section{$\S$ 2.2.2. Interludio}

En la primera fase de sus pesquisas, Bettini nos sitúa en la intimidad del juego de Crepereia con su muñeca. Pero, hacia la mitad del apartado oㅡ ("Muchacha, 'muchachita de ojo' y neuróspaton"), abandona abruptamente la escena del juego de la joven con su muñeca para intercalar una digresión donde comenta a dos autores romanos de la Antigüedad (el decisivo Interludio que reorientará crucialmente el rumbo de su ensayo).

Bettini acomete su digresión esbozando una distinción entre muñecas y estatuas: "a la muñeca", nos dice, "se responde de un modo que no es el mismo con que se responde a una estatua o al dibujo". Pero esta lacónica distinción, que diferencia las muñecas de las estatuas indicando que cada una de estas dos clases de imágenes provoca una modalidad específica de respuesta, es inmediatamente difuminada. En realidad, la diferencia no estaría en los objetos, sino en el dispar modo en que nos relacionamos con ellos. Ante la muñeca depositada en el templo a modo de exvoto respondemos del modo en que lo hacemos con una estatua: tratándola como monumento. Recíprocamente, podemos tratar a la estatua como a una muñeca: hablando con ella, vistiéndola o desvistiéndola, interactuando físicamente con ella como es sabido que hicieron el legendario Pigmalión con su estatua de marfil y, según nos informan diversas fuentes históricas, cierto muchacho con la Afrodita de Cnido.10

10. Del primero de estos dos afamados ejemplos de estatua empleada como muñeca procedentes de la Antigüedad (uno legendario, el otro histórico), es bien conocido el relato de Ovidio donde se nos dice que Pigmalión trataba a su imagen de marfil como a una mujer real: le hablaba, la vestía, le hacía regalos, la acosta- 
Bettini tiene interés en subrayar que "cualquier imagen puede convertirse en pupa" (2829) porque este hecho constituye la razón que lo lleva a examinar el testimonio de los dos autores romanos que lo inducen a replantearse drásticamente la forma en que estaba intentando responder la pregunta "¿qué tipo de imagen es una muñeca?". Considerando la importancia que tiene en el desarrollo del trabajo de Bettini la distinción entre muñecas y estatuas basada en el modo en que se interactúa con ellas, y dado que él apenas la insinúa, nos parece necesario intercalar a continuación un excurso que permita iluminar la contraposición del "comportamiento específico - la interacción" sugerido por la muñeca y el comportamiento "que se requiere frente a las estatuas y otros tipos de simulacro". Lo haremos comentando algunos pasajes del opúsculo "Las muñecas en el sistema de la cultura" de Yuri Lotman incluido en Muñeca. ${ }^{11}$

\section{§ 2.2.2.1. Excurso: Una estatua no se usa como una muñeca}

Lotman afirma que comprender "el secreto de la muñeca" pasa por distinguir la muñeca de la estatua. La primera es un "juguete", la segunda una "idea cultural", y cada una pertenece a un dominio cultural diferenciado. "La diferencia", indica Lotman, "radica en lo siguiente. Existen dos tipos de público: el 'adulto', por un lado, y el 'infantil', 'folclórico' o 'arcaico', por otro." (46) Lotman especifica estos dos tipos de público retratando el modo en que cada uno de ellos "se relaciona con el texto". Básicamente, el primero "recibe una información", el segundo "produce información mediante el juego".12

ba sobre tapices teñidos de púrpura de Sidón y la abrazaba, sintiendo que su carne cedía al contacto y temiendo que la presión de sus dedos dejara algún cardenal en los miembros que había apretado, etc. (Las metamorfosis, libro X, 243-297). De la no menos renombrada Afrodita de Cnido esculpida por Praxíteles es sabido que su efectividad como ídolo afrodisiaco alcanzó celebridad en todo el Mediterráneo porque despertó tal pasión en un joven noble griego que sus muslos aparecieron una mañana manchados de semen - "eiusque cupiditatis esse indicem maculam" escribe Plinio en su Historia natural, XXXVI, iv, 21. Además de Plinio, son varios los autores antiguos que relatan este episodio, entre ellos los griegos Luciano en su Amores y Filóstrato en Vida de Apolonio, los romanos Valerio Máximo en Facta et dicta memorabilia y Clemente de Alejandría (el primer "doctor de la Iglesia" cristiana y el primer miembro de la Iglesia de Alejandría en recibir notoriedad) en su Protréptico, donde se incluye un influyente alegato contra la idolatría en el que las estatuas son calificadas de "juguetes funestos" (o de "juguetes mortales" en otras traducciones).

11. Lotman, Yuri (2015), en Muñeca, págs. 45-53.

12. Al lector no le habrá pasado inadvertido que Lotman reduce la muñeca y la estatua a la condición de "texto", caracteriza como "público" tanto al usuario del juguete como al de la estatua, y a ambos los tipifica en función del modo en que gestionan "información": el primero la produce, el segundo la recibe. Veremos que más que de alguien que juega con una muñeca o contempla una estatua, Lotman habla de personas que asisten a una representación teatral, comportándose unas como el alborotado y entrometido público de un corral de comedias del siglo XVI, y otras como el público instruido y circunspecto que actualmente asiste a una representación en el Teatro de La Scala en Milán. (Para la formación del sentido moderno de "público", ver en La invención del arte. Una historia cultural, de Larry Shiner, el capítulo "Del gusto a lo estético" y el epígrafe "El aprendizaje de la actitud estética" del capítulo "Silencios: el triunfo de lo estetico".) Como Bettini, Lotman asume la petitio principii que postula que las imágenes son signos y que su razón de ser consiste en vehicular información. En un trabajo

Umática. 2018; 1: 57-104 
Mientras que el primero se comporta como un receptor de información contemplativo que sabe que "no hay que tocar", que "no hay que hacer ruido" y, sobre todo, que no hay que "intervenir" (46), el segundo (que no sabe) "participa en un juego", grita, y no se conforma con mirar sino que toca, se entromete, "da voz" a las imágenes, rompe o besa (46-47). En suma, mientras que el primero se comporta como un adulto capaz de mantener su cuerpo en estado de standby, que sabe guardar las distancias e interpreta "el texto", el segundo se comporta como un niño o un primitivo que pierde el control, se inmiscuye y manipula. La estatua pertenece al ámbito del público adulto, "se mira". La muñeca al del público infantil, "se toca, se manipula". La diferencia que permite distinguir la imagen que es una muñeca de la que es una estatua radica en esto: la primera es una imagen destinada a emplearse como un juguete, la segunda a ser leída como un oráculo.

En su argumentación acerca de la posición de la muñeca en el sistema de la cultura, el semiólogo ruso destaca otra diferencia importante: mientras que la muñeca, que "estimula la imaginación", "no invita a contemplar el pensamiento de otra persona, sino a jugar", la estatua "es un mediador que nos transmite una creación ajena", "encarna el elevado mundo artístico que el espectador no puede producir por sí mismo" y "reclama seriedad" (47-48).

Implícita en la contraposición estatua/muñeca argumentada por Lotman puede detectarse, según creemos, la articulación de una serie de polaridades:

\begin{tabular}{|c|c|}
\hline $\begin{array}{l}\text { E S T A T U A } \\
\text { - uso espiritual (conexión mental virtual) } \\
\text { - actitud distanciada y des-interesada } \\
\text { - madurez } \\
\text { - seriedad, reglas } \\
\text { - elemento mediador } \\
\text { - ajeno (que pertenece o es cosa de otro[s] } \\
\text { - del latín aliēnus, de alius, "otro") } \\
\text { - nosotros (compuesto con nos [plural } \\
\text { asociativo: yo \& quienes conmigo están] } \\
\text { + otro (del castellano antiguo autro, y } \\
\text { este de alt(e)ro, a partir del latín alter, de } \\
\text { aliēnus) } \\
\text { - vínculo contemplativo } \\
\text { - comunica, asocia } \\
\text { - elevado }\end{array}$ & $\begin{array}{l}\text { MUÑECA } \\
\text { - empleo manipulativo (contacto físico } \\
\text { fáctico) } \\
\text { - actitud comprometida y entrometida } \\
\text { - primitivismo, puerilidad } \\
\text { - informalidad, irresponsabilidad, capricho } \\
\text { - fin en sí mismo } \\
\text { - egoísta (del latin ego, "yo" + sufijo-ismo, } \\
\text { que denota tendencia) } \\
\text { - yo }\end{array}$ \\
\hline
\end{tabular}

Teniendo en cuenta estas polaridades, la argumentación de Lotman podría interpretarse así: mientras que la muñeca estimula un comportamiento imaginativo descontrolado e irresponsable (que no es serio), donde el individuo se deja llevar por las incitaciones físicas del juego involucradas por el con-tacto con la muñeca, sin pretender otra cosa que disfrutar haciendo eso que hace y, en su trato lúdicamente empático con el juguete, se involucra hasta el punto de difuminar las distancias y con-fundirse con él, comportándose de un modo innoble,

destinado a ilustrar la comprensión de "el secreto de la muñeca", es llamativa la crudeza con la que Lotman habla de la muñeca y la estatua aplicando un vocabulario tomado del discurso sobre el público teatral. 
la estatua es vista como un artefacto dispuesto por alguien (por otro[s]) como un texto, es decir, destinado a ser interpretado, de forma que su trato con la estatua no está centrado en ella, porque, viéndola como un medio que conduce a otra cosa y a través del cual recibe una información, el individuo pretende descifrarla. A diferencia de la muñeca, que es un artefacto que se manipula (como el cubo de Rubik), la estatua es un signo.

Jugar es una acción intransitiva. Interpretar es una acción transitiva. La primera se expresa con un verbo intransitivo: yo juego [crezco, corro, estornudo, etc.]. La segunda con uno transitivo: yo interpreto [contemplo, leo, como, etc.] algo. Mientras que jugar es una actividad idiota —en el sentido original del término: "idiota" proviene del griego ioı nombra a la persona que no se ocupa de los asuntos públicos, sino sólo de sus intereses-, interpretar es una actividad participativa (esta palabra proviene del latín participāre, derivada de participō: soy o tomo parte de algo, me involucro en algo). En el acto de la interpretación, la singularidad del individuo se difumina diluyéndose en un todo como parte de él, integrándose en algo no producido por él mismo, que está por encima de él y que lo eleva por encima de sí mismo (como Dios, según la tesis de Durkheim "Dios es la sociedad").

Adoptando el rol de la persona que recibe una información, el individuo que contempla una estatua (=interpreta "el texto") se enfrenta a un artefacto que reclama seriedad. Porque no se trata de jugar imaginando ad libitum el significado de la estatua, sino de interpretar como es debido una información que "el espectador no puede producir por sí mismo". Actuando así, el espectador se hace partícipe de un todo: la comunidad que ha instituido y maneja el código que dota de sentido a la estatua. En la medida en que su comportamiento se atiene a las estipulaciones previstas por el código, el individuo se involucra en un juego social[izado], que es "serio" porque, jugándolo, uno se in-corpora en una sociedad. Parafraseando a Merleau-Ponty podríamos decir: la statue est un geste et sa signification un monde. ${ }^{13}$ La idea tiene un pedigrí bien conocido: remite a la tradición del Sturm und Dran y el Romanticismo y a la filosofía del lenguaje de Herder y Wilhelm von Humboldt — que postula que "la lengua de un pueblo es, por decirlo así, el alma misma de este pueblo, convertida en visible y tangible"一, y se prolonga hasta en el "giro lingüístico" (y el "giro icónico") ilustrado con declaraciones como el famoso aforismo "los límites de mi lenguaje significan los límites de mi mundo", formulado por Wittgenstein en su Tractatus Logico-Philosophicus, o en la caracterización heideggeriana del lenguaje como "casa del Ser".

A diferencia del individuo lotmaniano que contempla una estatua, el primitivo y el niño ignoran (transgreden) el código, se relacionan con la estatua jugándola como a una muñeca: improvisando ad libitum actividades interactivas, inventando, ad hoc y en caliente, interacciones que conforman sobre la marcha juegos no estabilizados por reglas fijas, juegos que no reclaman seriedad.

La importancia fundamental del juego fue estudiada hace años por el historiador holandés Johan Huizinga en Homo ludens (1938), donde refutó la identificación del juego con

13. La frase de Maurice Merleau-Ponty es "La parole est un geste et sa signification un monde" ["El habla es un gesto y su significado un mundo"]. Aparece en su Phénoménologie de la Perception.

Umática. 2018; 1: 57-104 
lo "pueril", es decir, con lo referido por "una palabra que señala el carácter inmaduro de una actitud espiritual y expresa algo que está entre el infantilismo y la falta de equilibrio del adolescente" (Huizinga, 1944: 241). Huizinga argumentó la extraordinaria seriedad del juego demostrando que constituye el fundamento de la cultura y, por tanto, de la humanización del ser humano. La tesis principal de Huizinga destaca que el hecho de que la cultura surge en forma de juegos sociales que tienen una estructura definida y articulada, y enfatiza dos cuestiones que deseamos subrayar aquí:

[1르 Toda comunidad jurídica o estatal lleva, por naturaleza, una serie de características que también distinguen a una comunidad de juego. Mediante el reconocimiento recíproco de principios, que en la práctica actúan como reglas de juego, cualquiera que sea el fundamento metafísico que se les busque, se sostiene un sistema de derecho de gentes. La afirmación expresa del principio pacta sunt servanda [lo pactado obliga] implica efectivamente el reconocimiento de que la integridad del sistema descansa sobre la voluntad de jugar el mismo juego. En cuanto una de las partes se sustraiga a las reglas del sistema, o bien se derrumba todo el sistema del derecho de gentes, aunque sea por cierto tiempo, o la parte violadora debe ser expulsada de la comunidad, como un aguafiestas. (246)

[2므 La cultura exige siempre, en cierto sentido, "ser jugada" en un convenio recíproco sobre las reglas. (249)

Aquí se trata de juegos sociales y, por tanto, serios. Además están los juegos privados, a menudo improvisados en la intimidad y pueriles. Estos dos tipos de juegos se corresponderían con los dos tipos de público segregados por Lotman: el "adulto", por un lado, y el "infantil", "folclórico" o "arcaico", por otro", que se corresponden, a su vez, con los dos tipos de imagen que estamos considerando: la estatua y la muñeca. A diferencia de los segundos, cuyo contenido, lo mismo que el de los sueños, se teje y se desteje ad libitum sobre la marcha, los primeros ostentan un contenido compartido y, por tanto, estabilizado. Siendo así, este contenido brinda una referencia común, que sirve como fundamento garantizado de la realidad de lo tenido por real (que no es otra cosa que una construcción social, como evidenciaron los sociólogos Peter L. Berger y Thomas Luckmann en un influyente trabajo publicado por primera vez en 1966).

A diferencia de la muñeca, que es un artefacto que se manipula (como el cubo de Rubik), la estatua es un signo que remite a algo distinto de sí misma a ojos de alguien sólo porque esa relación se da gracias a un código socializado, es decir, ajeno. Es dicho código lo que ilumina a la estatua invistiéndola de sentido y encuadrándola en el sistema de una cultura al que se refiere Lotman.

Si en el caso del juego con la muñeca, el individuo se repliega puerilmente sobre sí mismo, en el del receptor de información que contemplando la estatua reconoce su significado, el individuo se despliega más allá de sí mismo. Por un lado, la informalidad primitiva (e innoble) 
de juegos privados como el de la niña con su muñeca. Por otro, la formalidad cívica (y elevada) de juegos públicos como el de la sociedad con sus monumentos.

\section{$\S$ 2.2.2.1.a. Estatuas vs. muñecas, humanitas vs. barbaritas \& feritas}

La contraposición que hace Lotman entre público adulto y público infantil, folclórico o arcaico - o, como veremos en el apartado siguiente, la sugerida por Bettini entre "hombres crecidos y barbados" serios, por un lado, y niñas y "hombres crecidos y barbados, se comportan como muchachas que juegan con muñecas", por otro- es uno de los tópicos fundamentales del Humanismo. Este tema aparece claramente perfilado en "La historia del arte en cuanto disciplina humanística" (1940), un ensayo clásico de Erwin Panofsky donde el fundador de la Iconología sitúa el origen de la noción de humanitas en "la confrontación entre el hombre y lo que es inferior a él" y explica "la clásica antítesis entre humanitas y barbaritas; o bien feritas" señalando

El concepto de humanitas con el significado de valor se formuló [en la Antigüedad .... Significaba así la cualidad que distingue al hombre no sólo de los animales, sino igualmente, y en mayor grado, de quien pertenece a la especie homo sin que por ello haya de merecer el calificativo de homo humanus,

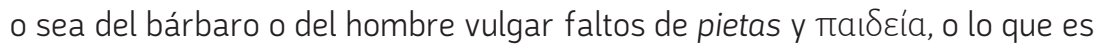
igual, del respeto por los valores morales y de esa agradable mezcla de saber y de urbanidad que sólo podríamos definir con el desacreditado término de "cultura". (Panofsky, 1985: 18)

Pertrechados con estas indicaciones, regresemos al texto de Bettini.

\section{§ 2.2.2.2. La irrupción de hombres con toda la barba}

Después de introducir la referencia a la distinción (borrable) de la estatua y la muñeca, Bettini interrumpe la historia de la muñeca de Crepereia e interpola el Interludio que articula las Escenas Primera y Segunda de su ensayo. En el Interludio, el autor de "Pupa" cita a dos autores antiguos de los que parece extraer la motivación con la que afronta por segunda vez la pregunta "¿qué tipo de imagen es una muñeca?"

En primer lugar, Bettini refiere unos pasajes donde el escritor latino y apologista cristiano Lactancio censura a quienes rinden culto a las imágenes de la diosa Venus y se mofa de quienes tratan estatuas salidas de las manos de Fidias, Eufránor o Polícleto como a "grandes muñecas: consagradas no por muchachas, cuyos juegos se pueden contemplar con indulgencia, sino por hombres con toda la barba" (29-30). Cita luego unas líneas del escritor romano Lucilio donde éste señalaba que es propio de los niños creer que las estatuas de bronce son seres vivientes (33). 
Antes de citar a Lucilio, e inmediatamente después de haber comentado a Lactancio, Bettini intercala crucialmente la siguiente apostilla: "Un comentario inevitable: ¿cómo no se dan cuenta de que, siendo hombres crecidos y barbados, se comportan como muchachas que juegan con muñecas innecesariamente grandes?" (p. 31) Bettini parece reparar ahora en que lo dicho anteriormente sobre la muñeca de Crepereia parecen comentarios de un hombre barbado de este tipo. Así que declara lo siguiente: "En este punto debemos preguntarnos: ¿qué tipo de imagen es entonces una muñeca?" Es la segunda vez que Bettini formula la pregunta, y es ahora cuando el autor de "Pupa" nos propone abandonar la escena lábil e infantil del juego íntimo de la joven con su muñeca para situarnos en el mundo cerrado e inmutable de los iconos: "Tratemos de enfrentarnos — nos insta - a la cuestión desde una perspectiva distinta pero inevitable, tratándose de un objeto icónico..." (31 las cursivas son nuestras).

\section{§ 2.2.3. Escena segunda: El juego público de la sociedad con la muñeca}

lluminado por Lactancio, el autor de "Pupa" acomete la Escena Segunda asumiendo que una muñeca es un "objeto 'icónico', es decir, un signo. Esta idea había sido adelantada ya, cuando, dando cuenta de algunas de las virtualidades del cuerpo de la muñeca, nuestro autor había señalado: "En realidad, todas estas características sitúan a la pupa más en el terreno del movimiento y la vida que en el de la inmutabilidad icónica" (27).

En la Escena Segunda, Bettini hace dos intentos de contestar (por segunda vez) la pregunta "¿qué tipo de imagen es la muñeca?". En el primero se mantiene pegado a la muñeca - aunque su interés ya no es averiguar qué hace, qué se hace con o qué se le hace hacer a la muñeca, sino averiguar qué significa.

Su primera respuesta es: "La muñeca es un signo que manifiesta una especie de autorreferencia", un signo que "tiende a escapar del mundo cerrado e inmutable de los iconos" (p. 32). Llega a ella después de haber descrito a la muñeca (27-28) diciendo que "se trata de una figura de muchacha" dotada de miembros articulados y provista de "senos, entre otros rasgos anatómicos" (por ejemplo: "orificios que permiten el uso de pendientes", "dedos ahusados que admiten los anillos", "cabellos auténticos que hacen necesario un pequeño equipo de peines", etc.), y que, "como persona real", además de peines, joyas, vestidos, muebles, etc., posee "un cuerpo que la hace persona capaz de cambiar su propia apariencia externa de acuerdo con las conveniencias o las necesidades impuestas por las normas culturales". El autor de "Pupa" explica que esta muchacha artificial "viva, o próxima a la vida", es una "imagen/no imagen que vive en el límite del mundo del movimiento y del sonido, dispuesta a participar en él si así se desea", y que

(...) interactúa con quien la posee; más concretamente, admite, e incluso exige, la manipulación: no se puede imaginar una muñeca, con su ajuar personal, sus muebles y utensilios domésticos, si no es como un objeto que existe para ser manipulado por los dedos de quien se entretiene con ella. (28) 
El propósito de esta descripción es ilustrar la idea de la muñeca como signo autorreferencial. Pero el autor de "Pupa" descarta esta posibilidad sin aclarar el motivo. Simplemente, desarrolla otra alternativa (la que dará por buena), después de intercalar el Interludio.

En su segundo intento de contestar, por segunda vez, la pregunta "¿qué tipo de imagen es una muñeca?", Crepereia ha muerto. El cuerpo viviente que manipulaba el cuerpo de marfil de la muñeca se ha convertido en vestigio de una joven malograda que, no habiéndose desprendido de su virginidad, no ha llegado a consumar su destino como mujer. Bettini sugiere que la muñeca, que reposa dentro del sarcófago junto a este vestigio de su ama, tampoco ha consumado su destino, que no era otro que llegar a ser monumento de la virginidad de su dueña. Veamos cómo argumenta este infortunio.

"Cuando Crepereia fue enterrada", nos dice, el significado que tenía la muñeca para ella se desvaneció. "Nunca lo sabremos" (las cursivas son nuestras). Lo que sí sabemos, nos dice el autor de "Pupa", es que "ese final debía constituir el acto más importante del juego", porque

\section{Las fuentes antiguas coinciden en efecto en afirmar que en vísperas de sus bo- das las vírgenes, griegas y romanas, consagraban sus muñecas a la divinidad, cumpliendo lo que se puede definir como un típico "rito de separación". (38)}

Depositando la muñeca en el templo, la joven que iba a casarse llevaba efectuaba el "acto final en que culminaban los 'juegos de muñecas' de la muchacha antigua", la acción que marca "la función de la muñeca en la cultura antigua" (38). Y es en este acto donde Bettini descubre, al fin, la respuesta a su pregunta. Porque, como dice más adelante, la muñeca es ofrecida por su dueña a la diosa a modo de exvoto por "aquello que dentro de un momento ya no existirá" (41-42). Eso que dentro de un momento ya no existirá es la virginidad de la joven que va a casarse. Así pues,

(...) no hay duda de que la organización cultural antigua atribuía a la muñeca un marco de "sentido" muy preciso dentro del cual moverse: la muñeca significa virginidad, la pupa, al existir, identifica a una clase de edad concreta y significa en relación con su joven dueña. En otras palabras, la muñeca funciona como un signo que vehicula un significado absolutamente diferenciado y de extraordinaria fuerza cultural. Tan diferenciado, y tan preciso, que en el momento en que la muchacha abandona su estado virginal para convertirse en esposa la muñeca ya no puede quedarse con ella. (42).

Depositada en el templo, la muñeca se convierte en "un objeto cargado de pasado", "representa el rígido equivalente de una edad, física y cultural, irremediablemente perdida", y "se transforma en el simulacro de un tiempo ( $y$ de una persona) que han existido pero se han vuelto irremediablemente lejanos: es el único testimonio de un mundo [... que] se cancela con un ceremonial complejo y, esta vez, real (43, las cursivas son nuestras). Así culmina Bettini su 
ensayo. La muñeca es una imagen que significa virginidad. Ésta es su respuesta a la pregunta "¿qué tipo de imagen es una muñeca?"

Es en el templo donde el destino de la muñeca se consuma. Es entonces, mediante este ceremonial complejo, cuando la pupa llega a ser esto que estaba destinada a ser. Es gracias a este juego público socialmente establecido, un juego "esta vez, real", cuando finalmente el corazón de lo que importa, la realidad de la realidad de la muñeca, se hacen patentes y queda fijada definitivamente.

La muñeca, en general, es una imagen que "representa la condición de virgen". Pero, dado que la muñeca ofrendada por cada joven "funciona como su proyección, su imagen virginal" (las cursivas son nuestras), cada muñeca, en particular, sería un monumento a la virginidad de "su joven dueña" - es decir, es una obra pública[da] y patente erigida por una comunidad a modo de memento, para preservar, rememorar y conmemorar la memoria de la virginidad de su joven, y ya inexistente, dueña.

\section{$\S$ 2.2.4. Conclusión: La muñeca es una imagen que significa virginidad - Paradojas y aporías}

El ensayo de Bettini entraña algunas dificultades. Entre ellas, el hecho de preguntar qué tipo de imagen es una muñeca dando por descontada una parte fundamental de la respuesta. Bettini asume como punto de partida la hipótesis una imagen es un signo icónico — es decir algo que hace pensar en algo distinto de sí mismo porque su conformación física es semejante a la de su referente ${ }^{14}$. El planteamiento es problemático porque anida en él una petitio pricipii: la presunción imagen = signo. Además, resulta paradójico porque lo que nos ofrece la respuesta de Bettini no es tanto una tipificación taxonómica del género de imagen al cual podría ser adscrita la muñeca (imágenes antropomórficas, imágenes empleadas como juguete, etc.), como una especificación del significado atribuido a la muñeca en el en el marco de la

14. La noción de signo icónico procede de la clasificación de los signos en función de su vínculo con el referente propuesta por Peirce, que los catalogó como iconos, símbolos e índices. La noción de iconismo entraña la presunción de que las imágenes remiten a su referente porque son semejantes a él. Gombrich desmontó esta presunción en Arte e ilusión (1960), haciendo ver que la percepción de parecidos depende de convenciones y que toda producción de imágenes está sustentada sobre la manipulación de "esquemas" convencionales. A partir de aquí, la idea de que entre la imagen y su referente existe una semejanza intrínseca o natural fue atacada drásticamente por Goodman y Eco (el primero desde la teoría de la referencia, el segundo desde la semiótica). Gombrich reaccionó al radicalismo del enfoque convencionalista llamando la atención sobre el hecho de que, aunque toda producción de imágenes depende de convenciones, hay imágenes que parecen mantener una relación de semejanza "natural" con ciertas cosas del mundo (por ejemplo, en "Imagen y código: alcance y límites del convencionalismo en la representación pictórica", en La imagen y el ojo, 1987, y en su último "Prefacio" a Arte e ilusión). También Eco se ha retractado de sus planteamientos más maximalistas, viéndose en la necesidad de tener que incorporar un epígrafe titulado "No era una discusión entre chiflados" en su repaso a "El debate sobre el iconismo" incluido en el capítulo "Iconismos e hipoiconos" de Kant y el ornitorrinco [ver nota 30]). Para una exposición resumida de los argumentos puestos en liza en la controversia sobre el iconismo, ver "§35. Crítica de la iconicidad" en Zamora Águila, 2007. 
cultura grecorromana, de forma que la "tipo" de imagen que es una muñeca es: imagen que significa virginidad. Clasificando las imágenes así, lo que resulta no es un sistema categorial articulado a modo de Árbol de Porfirio, sino una nomenclatura. Finalmente, la respuesta del autor de "Pupa" a la cuestión qué es una muñeca aboca a una aporía, ya que, afirmando que es un signo, también declara que la existencia "inmutable" de la muñeca es mental o, dicho de otra forma, que las muñecas no existen. Volveremos sobre esto en el apartado \& 3 .

Fuera cual fuera el empleo semiótico asignado a las muñecas en la Antigüedad grecorromana ${ }^{15}$, Bettini sabe que los romanos las hacían del modo en que las hacían para que estos artefactos ${ }^{16}$, concebidos como útiles al servicio de un propósito bien definido, resultaran útiles en el desempeño del empleo al que estaban destinados: servir como partner de las niñas.

Lo sabe, pero fija su razón de ser afirmando que una muñeca es un signo. Suponemos que la razón de que opte por esta respuesta tiene que ver con lo referido en el apartado § 2.2.2.1. A diferencia de los profesionales de la industria juguetera implicados en el negocio de las muñecas, los estudiosos de la cultura que se interesan por las muñecas no parecen estar interesados en comprender las virtualidades fácticas de estas imágenes. Su objetivo no sería averiguar "qué hace", "qué se hace con" o "qué se hace hacer a" una muñeca, sino especificar su significado en el marco de la realidad instituida mediante el juego serio practicado por hombres con toda la barba — que tiene su lugar en la esfera del universo simbólico de Cassirer, y no en la del juego de la niñas con sus muñecas.

15. Naturalmente, antes que del empleo semiótico asignado a las muñecas en la Antigüedad grecorromana, en singular, habría que hablar de una de trama plural de significados. Bettini asegura que muñeca significa imagen que denota virginidad. Esta interpretación coincide, en parte, con lo consignado por Diderot y D'Alembert en la entrada "Poupées" de la primera edición de la Encyclopédie, donde se menciona a las muñecas romanas indicando que las jóvenes solteras ofrendaban las muñecas con las que habían jugado en la infancia en el altar de Venus (Veneri donatae una puppae virgen), sugiriendo que el sentido de este ritual podría significar que estaban preparándose para las ocupaciones serias del matrimonio y se despojaban de estas insignias de la infancia, o, quizá, que pedían que se les concedieran niños bonitos. Actualmente son muchos los autores que coinciden señalando que estos juguetes (que son imágenes de jóvenes desnudas que poseen características físicas de una mujer adulta: pechos moldeados, cintura estrecha, caderas anchas y, en algunos casos, genitales delineados) estaban destinados a educar la conciencia de género de las niñas. En "Playing with Gender: Girls, Dolls, and adult Ideals in the roman World", Fanny Dolansky, distingue estas imágenes enfatizando el hecho de que estos rasgos las convierten en "the only explicitly gendered toys from the Roman world, these constitute unique bodies of evidence for exploring questions of socialization and identity formation, and assessing ancient ideals", y señalando que, por sus características morfológicas, "the dolls' multivalence as artifacts of gender and status is revealed" (Dolansky, 2012: 256).

16. Un artefacto puede definirse como un objeto que ha sido producido intencionalmente para un propósito determinado, de forma que sus hechuras dependen del fin al que está destinado, es decir, de la "causa final" que constituye su "razón de ser". La Stanford Encyclopedia of Philosophy define "artifact" así: "A standard philosophical definition of "artifact" — often assumed even when not explicitly stated — is that artifacts are objects made intentionally, in order to accomplish some purpose. This definition is rooted ultimately in Aristotle's distinction between things that exist by nature and things that exist by craft (Metaphysics 1033a ff., Nicomachean Ethics $1140 a$ ff., Physics192b ff.). Those that exist by nature have their origin in themselves, whereas those that exist by craft have their origin in the craftsperson-specifically, in the form of the thing as it exists in the mind of the maker." (https://plato.stanford.edu/entries/artifact/, consultado el 28-III-2019)

Umática. 2018; 1: 57-104 
Respondiendo "es una imagen que significa virginidad" a la pregunta "¿qué tipo de imagen es una muñeca?", Bettini no explica cómo sirve la muñeca haciendo de partner en los juegos de la joven - y cómo lo hace en varios de los diversos usos comunes del verbo "servir": estar al servicio de alguien, por ej.: sirviendo como criado o sirviente; ejercer un empleo, por ej.: servir como barítono o malabarista; ser a propósito para determinado fin, como en "estas tijeras sirven para podar"; $y$, finalmente, aprovechar, valer, ser de utilidad, como en "este destornillador [no] sirve para atornillar este tipo de tornillo". En vez de ofrecer una respuesta que dé cuenta del modo en que una muñeca sirve como partner de su dueña en sus juegos, Bettini se limita a señalar su significado, como quien indica que cierta señal de tráfico de color blanco, que tiene forma circular, un borde rojo y un pictograma negro de "automóvil" en el centro significa "entrada prohibida a vehículos de motor, excepto motocicletas de dos ruedas".

Explicar así qué clase de señal de tráfico es ésta parece razonable, dado que la razón de ser de este artefacto no es otra que la de servir como signo —estando a la vista erguida sobre un poste junto a la calzada-, para dar instrucciones o proporcionar una información a los usuarios de las carreteras (aunque es cierto que, aprovechando ciertas affordances de la señal de tráfico, este artefacto también podría servir siendo empleado como maza para golpear la luna de un escaparate; pero éste es un uso adventicio que no explica qué es esta señal de tráfico).

Explicar qué tipo de imagen es una muñeca afirmando que es una imagen que significa virginidad es como explicar qué es un bastón de ciego indicando que "es una vara ligera y alargada que identifica a las personas ciegas"17. No parece que ésta sea una forma adecuada de hacer saber qué es un bastón de ciego. Es cierto que el bastón de ciego, cuando es blanco, también sirve como signo que denota ceguera en determinados contextos culturales. Pero éste es un uso adventicio del bastón de ciego, y una respuesta a la pregunta "¿qué es un bastón de ciego?" que se limite a indicar que es algo que denota ceguera (omitiendo que es una vara que permite al invidente detectar, palpar e identificar lo que hay a su alrededor, y lo ayuda a localizar obstáculos o marcas de orientación, etc.) no puede ser tenida por una explicación plausible de lo que un bastón de ciego es. Sucede lo mismo con una respuesta a la pregunta "¿qué tipo de imagen es una muñeca?" que omita la referencia a su razón de ser como muñeca.

Lo asombroso de "Pupa. La muñeca en la cultura griega y romana" es que su autor (a diferencia de Lotman, que ni siquiera tiene la delicadeza de emplear un lenguaje adaptado al asunto de la muñeca) conoce y toma en consideración el hecho de que la muñeca es un artefacto concebido y diseñado ex professo para servir como partner de las niñas en sus juegos, pero, a la hora de explicar qué es una muñeca, lo ignora y dice que es una imagen que significa virginidad. Nuestro interés en este ensayo resulta de este proceder extraordinario,

17. Tomamos esta definición de la entrada "Bastón Blanco" de la Wikipedia (https://es.wikipedia.org/wiki/ Bast\%C3\%B3n_blanco, consultada el 17-3-2019), a la que nos remite el motor de búsqueda de Google cuando se introduce la expresión "bastón de ciego, Wikipedia" como término de búsqueda. 
que, a nuestro entender, ilustra bien el modo en que la doctrina canónica de "la imagen" se relaciona (lotmanianamente) con las imágenes.

Qué duda cabe, se puede hacer un análisis semiótico de la muñeca (lo mismo que del televisor, el consumo de galletas o la sonrisa), y se puede teorizar semióticamente sobre las imágenes. De hecho, hay que reconocer que la aportación de la Semiótica al discurso sobre las imágenes — con ocasión del debate sobre el iconismo— ha tenido el saludable efecto de clarificar y sanear la vaguedad y, en ocasiones, el oscurantismo del discurso tradicional sobre las imágenes. Distinto es asumir que la comprensión semiótica de las imágenes aporta la clavis universalis que explica lo que una imagen $\mathrm{es}^{18}$.

$\mathrm{Si}$ —en vez de seguir dando por descontado que la única respuesta cabal a la pregunta "¿para qué sirve una imagen?" es "sirve para pensar en otra cosa" - nos planteamos la posibilidad de que hay imágenes que, además de servir para que alguien pueda tomarlas como algo que está en lugar de otra cosa — siendo in mente el lugar donde están en lugar de esa otra cosa- (cualquier cosa sirve para esto), sirven para que alguien pueda emplearlas fácticamente como algo que está en lugar de otra cosa — siendo in mundum el lugar donde están en lugar de esa otra cosa-, entonces quizá empecemos a estar en condiciones de sortear el impasse el que se encuentra la teoría de las imágenes. Porque es bastante probable que Mitchell esté en lo cier to cuando afirma "Quizá el problema no esté sólo en las imágenes, sino en la teoría", y seguro que conviene atender la indicación —-tomada de Goodman — que nos advierte: Si todos los intentos de contestar la pregunta "iqué es una imagen?" acaban típicamente en frustración y en confusiones, tal vez haya que plantearse que la pregunta no es la adecuada $^{19}$. (Esto último, naturalmente, no vale para todo aquello de lo cual decimos que es una "imagen". No vale para Peppa Pig, tampoco para la inscripción $\$ Pero sí para una prótesis dental, un avión de papel y ciertas muñecas.

Summa Summarum. Asumiendo, (1ํํ) que, aunque la hipótesis de Lamarck "la función crea el órgano y la necesidad la función" no resulta plausible como explicación de la morfología zoológica, sír resulta convincente cuando, mutatis mutandi, es aplicada a los artefactos y, considerando ( $2^{\circ}$ ) que las muñecas, a diferencia de las señales de tráfico, no son artefactos cuya razón de ser consiste en ser empleados como signos, entendemos que una explicación sensata de qué es la muñeca de Crepereia pasa por describirla como una especie de mas-

18. Decimos esto pensando en un pasaje del capítulo "Iconismo e hipoiconos", de Kant y el ornitorrinco, donde Eco, refiriéndose a la querelle del iconismo, y tratando de justificar su papel en la misma como activista antirreferencialista (iconofóbico), declara: "Esto sucedía en un momento en el que la indagación semiótica se estaba proponiendo [a sí misma] como clavis universalis capaz de reconducir a convenciones culturales analizables todos los fenómenos de comunicación" (Eco, 1999: 397). Conviene señalar que entre los fenómenos de comunicación referidos por Eco, se incluía, por ejemplo, la interacción entre un linfocito y un antígeno. Aunque Eco ha reconsiderado su posición respecto del iconismo, son muchos los autores que aún batallan alineados en el bando del antirreferencialismo.

19. La frase de Goodman en la que nos inspiramos es "Si todos los intentos de contestar la pregunta '¿qué es el arte?' acaban típicamente en frustración y en confusiones, tal vez - y como tantas veces acontece en filosofía- haya que plantear que la pregunta no es la adecuada". La tomamos del capítulo "¿Cuándo hay arte?" de Maneras de hacer mundos (Goodman, 1990: 87).

Umática. 2018; 1: 57-104 
cota artificial: es una mujer de marfil que sirve como partner de juego para su dueña, porque ésta puede engalanarla con joyas y vestidos o con un camisón según la ocasión, también puede desvestirla y asearla y, además, no sólo puede hacerle confidencias, también puede dialogar de ella del modo en que se dialoga con algunas mascotas. La explicación que reduce las imágenes a la condición de signos es adecuada para los Estudios Visuales (Visual Culture), que pretenden dilucidar el significado social de las imágenes, su incidencia en la constitución del imaginario público, el impacto de la emergencia de la "civilisation de l'image" sobre la "civilisation du livre", etc. Pero no da cuenta de usos no semióticos de las imágenes, como cuando las empleamos como prótesis dentales, ni consigue explicar los propósitos de la voluntad naturalizadora que produce útiles como la muñeca de Crepereia o las muñecas ginoides a las que nos referiremos más adelante (en \& 5.1.).

\section{§ 3. Las imágenes no existen}

Las imágenes, como sabemos, son diferentes del resto del mundo: no existen. "Tocar la obra" es degradarla al estado de un objeto y, de una manera muy fundamental, ofender su esencia, que pertenece a la imaginación.

"No existe la imagen en sí misma." Así comienza el texto de la contraportada del libro de Régis Debray Vida y muerte de la imagen. La frase "Il n'y a pas d'image en soi" aparece también en la reseña de este libro aportada por la editorial Gallimard. Éste es un dato significativo, porque lo que se nos ofrece en la contraportada y en la reseña editorial de un libro no es un resumen, sino un reclamo destinado a persuadir al lector potencial para que compre - su objetivo es "rematar la venta". Considerando que la elección de este reclamo ha sido cuidadosamente calculada por expertos en marketing, hay que pensar que la idea de que la imagen no existe debe ser muy tentadora — quizá porque contraviene el sentido común, o puede que porque entraña una apuesta ideológica tenida por crucial.

En su Breve historia de la imagen, Michel Melot la aclara explicando "La imagen no es una cosa, sino una relación" (Melot, 2010: 12). Maurizio Vitta desarrolla esta aclaración en El sistema de las imágenes:

[L]a imagen no se define por lo que es, sino por aquello a lo que remite, su modelo, respecto al cual se revela, sin embargo, sólo como un enigmático reflejo. En consecuencia es ella misma, pero sólo en la medida en que se presenta como algo distinto. Si se muestra ante nosotros en forma de objeto real —un dibujo sobre papel, tela, madera, una pared o una pantalla electrónica- es aspirada por la materia inerte hasta disolverse en la insignificancia. Como la 
Bella Durmiente del cuento sólo el beso del príncipe —la revelación de su contenido a la conciencia puede infundirle vida ${ }^{20}$. (Vitta, 2003: 31)

Tocar la obra, afirma Stoichiță, es degradarla al estado de un objeto. Y no sólo porque supone retrotraerla al estado de cuerpo, haciendo así que sea reabsorbida por la materia —como podría sugerir la exhortación bíblica noli me tangere (Juan 20:17)—, también porque el apetito y la necesidad de verificación que impulsan a tocar suponen una regresión a cuerpo de la persona que palpa (y que, tentando, se expone ella misma al riesgo de ser tentada y reabsorbida por la materia). La revelación no requiere contacto.

Las imágenes no existen —es decir, no del modo en que existen las rocas y las ranas-, la suya es una existencia ficticia. En el más robusto de los casos, su existencia es la de una ficción tan vigorosa como la del Quijote o la del dólar ${ }^{21}$. En el más débil, como la de una ensoñación que se desvanece en el olvido. Dado que la existencia de las imágenes es una existencia vicaria (ya que son en función de otra cosa), de las imágenes se dice que adolecen de un déficit ontológico. Es por esto que, como ha señalado Cruz Revueltas, la imagen ha sido y sigue siendo objeto de una "devaluación ontológica", y es porque "carece de la sustancialidad y de la inmutabilidad del 'mundo verdadero', el de las ideas inalterables y eternas, revelado por la intuición intelectual" (Cruz Revueltas, 2009: 42) que se dice, que las imágenes no existen. Ésta es una de las proclamaciones más audaces de la doctrina canónica de la imagen.

Uno de los pasajes más asombrosos de Mitchell es un fragmento de "¿Qué es una imagen?" donde este autor, siempre brillante, ofrece la mejor explicación que conocemos sobre la inexistencia de las imágenes. Es la siguiente:

Si no hubiera mentes tampoco habría imágenes, ni mentales ni materiales. El mundo puede no depender de nuestra conciencia, pero las imágenes en el mundo (ya no digamos, las del mundo) evidentemente sí. Y esto [...] porque una imagen no puede verse como tal sin un truco paradójico de la conciencia, la habilidad de ver algo como si "estuviera" y "no estuviera" al mismo tiempo. Cuando un pato responde a un señuelo o cuando los pájaros picotean las uvas en las legendarias pinturas de Zeuxis, no están viendo imágenes; están viendo a otros patos o uvas reales (las cosas mismas y no imágenes de las cosas).22 (Mitchell, 2011: 119)

20. Cfr. con lo dicho en § 3.2.2.1 acerca de la construcción social dela realidad.

21. "El que toma un dólar de papel a cambio de veinticinco manzanas — ha explicado Panofsky — realiza un acto de fe, y se somete por lo mismo a una doctrina teórica igual que hacía el hombre de la Edad Media que compraba una indulgencia." Tomamos este pasaje de "La historia del arte en cuanto disciplina humanística" (Panofsky, 1985: 17-43). Con su referencia al uso del dinero, Panofsky anticipó una tesis desarrollada más de medio siglo después por el historiador Yuval Noah Harari en Sapiens: De animales a dioses: Una breve historia de la humanidad (2014).

22. Traducción modificada por nosotros. La edición española traduce "an image cannot be seen as such" por "una imagen no puede considerarse como tal". La frase completa es "It is because an image cannot be seen as Umática. 2018; 1: 57-104 
La argumentación que lleva a concluir "si no hubiera mentes tampoco habría imágenes" resulta tan plausible que conviene sondearla cuidadosamente, porque deja un resto que no deberíamos dejar abandonado a su suerte. Como Bettini, Mitchell asume el dogma que postula que ser una imagen es ser un signo. Situados en esta presunción, el razonamiento de Mitchell es perfectamente congruente con la explicación de los signos ofrecida por la Semiótica —que Umberto Eco presenta así en su libro Signo:

Una cosa es cierta: en cualquier clasificación del signo como elemento del proceso de significación siempre aparece como algo que se pone en lugar de otra cosa, o por alguna otra cosa. Peirce lo define como "something which stands to somebody for something in some respect or capacity" (Peirce, 1931, 2228), definición que se puede traducir así: algo que a los ojos de alguien se pone en lugar de alguna otra cosa, bajo algún aspecto o por alguna capacidad suya. "Bajo algún aspecto" quiere decir que el signo no representa la totalidad del objeto sino que - mediante diferentes abstracciones - lo representa desde un determinado punto de vista o con el fin de alguna utilización práctica. (Eco, 1994: 27-28)

De lo dicho se derivan dos cosas. Por un lado, que ningún objeto es, por sí mismo, un signo. Esto es lo que afirma la definición de signo formulada por Charles Morris en 1938:

[A]lgo es un signo sólo porque un intérprete lo interpreta como signo de algo [...], por tanto, la semiótica no tiene nada que ver con el estudio de un tipo de objetos particular, sino con los objetos comunes en la medida en que (y sólo en la medida en que) participan en la semiosis. ${ }^{23}$

Por otro lado, que si no hay una mente que, percibiendo cierta cosa, la correlaciona con otra en su mente, entonces tampoco hay signo. Algo es un signo porque/cuando alguien lo co-

such without a paradoxical trick of consciousness, an ability to see something as 'there' and 'not there' at the same time" (Mitchell, 1986: 17). Merece la pena llamar la atención sobre el "truco" mencionado por Mitchell y la "habilidad" de la cual depende, porque remiten a esa capacidad, reivindicada por la tradición humanista como el rasgo genuinamente humano del ser humano, que permite instituir "la clásica antítesis entre humanitas y barbaritas" - y que es congruente con el imperativo kantiano que exige a la persona con buen gusto que "En un producto del arte bello hay que tomar conciencia de que es arte y no naturaleza" (en "\$45. El arte bello es arte en cuanto, al mismo tiempo, parece ser naturaleza", Crítica del juicio). Frente al esquema diádico "estímulo/respuesta", situado en el dominio de la animalidad, el esquema tríadico "signo/mente/significado" genuino del ser humano: "Un proceso de comunicación en el que no exista código, y por consiguiente en el que no exista significación, queda reducido a un proceso de estímulo-respuesta. Los estímulos no se adecúan a una de las definiciones más elementales del signo, la que dice que se pone en lugar de otra cosa. El estímulo no se pone en lugar de otra cosa, sino que provoca directamente esta otra cosa. Una luz deslumbrante que me obliga a cerrar los ojos es una cosa distinta de una orden verbal que me imponga el cerrar los ojos. [...] En este sentido, es estímulo el sonido de la campanilla que induce al perro del experimento de Pavlov a salivar..." (Eco, 1994: 22-23).

23. Tomamos la definición de Eco 1995: 22. 
rrelaciona mentalmente con otra cosa y, como afirma una célebre declaración de Charles Peirce: "Nothing is a sign unless it is interpreted as a sign" (Peirce, CP. 1931-1935, 2.308). Por eso subraya Eco que todo signo lo es a los ojos de alguien.

Teniendo esto en cuenta, se comprende que la argumentación de Mitchell es semióticamente impecable. Cuando se acepta que las imágenes son signos, también hay que asumir que no existen como existen las rocas y las ranas, que sólo existen del modo en que existen el dólar, el Quijote y las ideas inalterables y eternas reveladas por la intuición intelectual. Aquí reside el fundamento de la afirmación de Mitchell "Si no hubiera mentes tampoco habría imágenes, ni mentales ni materiales".

Argumentaremos contra esta forma de entender las imágenes ( $\$ 5-\S 6)$. Pero antes quisiéramos presentar un escenario apocalíptico para ver qué pasaría con las imágenes.

\section{§ 4. W. J. T. Mitchell: patos \&t mágenes de pato tatusas-pato}

En "¿Qué es una imagen?", Mitchell evoca un escenario apocalíptico donde "mi mente, las suyas y toda la conciencia humana fueran liquidadas". Si sucediera tal cosa, "el mundo físico continuaría existiendo estupendamente sin nosotros", pero la existencia de las imágenes cesaría. Esto dice Mitchell.

Aceptemos dócilmente el dictum de Mitchell, y probemos a imaginar la siguiente escena post-apocalíptica: los señuelos de pato dispuestos sobre las aguas de un lago por un cazador que, un instante antes de que ocurriera la catástrofe, se disponía a cazar, siguen ahí. Como no hay mentes dotadas de "la habilidad de ver algo como si 'estuviera' y 'no estuviera' al mismo tiempo", no se puede llamar "imagen" a esas cosas que, mecidas por las ondulaciones del agua, se bambolean sobre la super ficie del lago entre patos de carne y hueso, que se relacionan con ellas del modo en que lo hacen con los patos - o más precisamente, como con otro tipo de pato, ya que hay que suponer que, aunque los patos de carne y hueso que "están viendo a otros patos reales" carecen de mente (en el escenario imaginado por Mitchell), acabarán dándose cuenta que estos patos no nadan como ellos, ni graznan como ellos, etc.

Tenemos ahí, entre los patos, los señuelos bamboleándose sobre la superficie de lago. La forma de sus cuerpos es como la del cuerpo de los patos. Tiene el mismo aspecto, arroja la misma sombra y genera los mismos reflejos en el agua. Su existencia no depende de nuestra conciencia, así que es objetiva y tan de verdad como la de las ranas, las rocas y los patos de carne y hueso. Como estamos acatando el dictum de Mitchell, de estas cosas no podemos decir que son imágenes. ¿Significa esto debemos aceptar también que, si no las llamamos imágenes, entonces ya no podemos hablar de ellas, que no deberíamos hablar de ellas? Pensamos que no, y nos parece que el hecho de que en vez de llamarlas imágenes las llamemos tatusas, por ejemplo, no extingue nuestro interés por ellas ni merma nuestra voluntad de estudiarlas con seriedad y objetivamente, con el propósito de conformar conocimiento científicamente riguroso sobre ellas.

La dificultad planteada por la conclusión derivada de esta fantasía apocalíptica es que, aunque las imágenes, tal como las entiende Mitchell, no son otra cosa ficciones, y la suya es Umática. 2018; 1: 57-104 
una realidad fingida, en el mundo hay tatusas. Algunas son las tatusas-pato que llamamos señuelo de pato, otras son las tatusa-mujer que llamamos estatuas o muñecas.

Si nos interesamos por las tatusas, ¿es que algo va mal? Ésta parece ser la insidiosa sospecha latente en gran parte del discurso sobre las imágenes - a pesar de la diversidad aparente de enfoques en los que éste es desplegado. Un par de ejemplos.

(Primero) En "La forma* y el consumidor", Rudolf Arnheim declara lo siguiente:

Una estatua que representa a una mujer es una mujer, no la forma de una mujer; esto es igualmente válido para una Venus romana que para una Virgen gótica, y también para las tallas africanas en madera y las figuras reclinadas de Henry Moore. En realidad hasta la mujer es parte de la forma que desaparece para dejar lugar tan sólo la pura encarnación visible de un significado o personaje. Si, en lugar de significado y personajes, vemos un cuerpo humano de carne y hueso [...] es que algo va mal en la figura. (Arnheim, 1986: 20)

(Segundo) Entre las aportaciones al discurso contemporáneo sobre las imágenes tenidas por clásicas, una de las más indiscutibles es Los lenguajes del arte. Una aproximación a la teoría de los símbolos (1968), de Nelson Goodman. El primer capítulo de este libro se titula "La realidad reconstruida", y se cita a menudo como exposición magistralmente rigurosa y lúcida de la refutación de la creencia ingenua en que la representación funciona imitando la forma externa de lo representado. Siguiendo la costumbre, Goodman encabeza el capítulo con un epígrafe - es decir, con una cita tomada de un autor conocido que sintetiza o ilustra la idea general del capítulo, aunque, en este caso, la autoría de la cita no está clara: Goodman especula con que le pueda ser atribuida a Virginia Woolf. En cualquier caso, si el autor de Los lenguajes del arte colocó ahí esta sentencia a modo de epígrafe, debemos que su contenido le parecía especialmente orientativo. La frase es "El arte no es una copia del mundo real. Con uno de estos malditos mundos basta." (Goodman, 2010: 19). No hace falta comentarla.

Aunque Arnheim sugiere que algo va mal si cuando miramos una Venus romana, en vez de ver un significado, nos comportamos como los patos de Mitchell y respondemos del modo en que lo hacemos ante la presencia de un cuerpo humano de carne y hueso, y aunque Goodman insinúa que a-copiar cosas de este maldito mundo es reprobable, las tatusas son un tema de interés muy legítimo para todo aquél que pretenda formarse una comprensión seria de las imágenes - también, como vamos a ver a continuación, para los fabricantes de prótesis dentales y de muñecas. 


\section{$\S 5$. Ernst H. Gombrich: ¿Tiene que ser siempre cier to que una imagen es una representación?}

"¿Tiene que ser siempre cierto que una imagen es una representación?"24 La pregunta parece clara y simple, pero conviene prestar atención al funcionamiento de las palabras "siempre", "es" y "representación", porque, aunque pensarse que lo se pregunta es si una imagen es siempre una representación (en el sentido de ¿podríamos afirmar que todas las imágenes son representaciones?), el interrogante planteado por esa pregunta no puede ser este.

Empecemos por la palabra "representación". La respuesta habitual a la pregunta "¿qué es una imagen?" suele ser: "es una representación de una persona o una cosa"25. El sustantivo "representación" remite a la acción y al efecto de representar, es decir, a la operación y al resultado de actuar en nombre de algo (otra persona o entidad) o de estar en lugar de (o por) otra cosa: "el embajador representará al Gobierno de su país", "este cuadro representa un paisaje holandés". Tenemos entonces que el sentido de la frase "una imagen es una representación" sería: una imagen es algo que, estando ahí presente (físicamente, in praesentia), ostenta un aspecto que hace que, en la mente de quien lo mira, se haga presente (in absentia) la idea de otra cosa. La conclusión es obvia: representación = signo. Ésta es la forma en que Mitchell da cuenta de la noción "representation" en su aportación al compendio Critical Terms for Literary Study, donde no sólo describe las representaciones afirmando que son "things that 'stand for' other things", es decir, "signs — things that "stand for" or "take the place

24. Adaptamos el interrogante planteado por Gombrich en "El poderío de Pigmalión" - que es el primer capítulo de la sección segunda de Arte e ilusión, significativamente titulada "Función y forma" (merece la pena reparar en este título, porque señala un asunto de particular interés: el expresado mediante la máxima "form follows function", que, como es sabido, es el lema del diseño funcionalista, pero también uno de los principios rectores del modo en que Gombrich aborda la comprensión y la explicación de las imágenes — también nosotros). El pasaje que inspira la frase "¿Tiene que ser siempre cierto que una imagen es una representación?" es el siguiente: "¿Tiene que ser siempre cier to que la cama del escultor es una representación? Si con este término queremos decir que tiene que referirse a otra cosa, que es un signo, entonces esto dependerá sin duda del contexto. Póngase una cama real en el escaparate de una tienda, y ya está convertida en signo. Cierto es que si no debe tener otra función, puede escogerse una cama que en efecto no sirva para otra cosa. También puede hacerse una imitación en cartón" (Gombrich, 2002: 84).

25. Esta comprensión de las imágenes se concreta en la forma en que usamos la palabra "imagen" y aparece consignada en la Wikipedia y registrada en el Diccionario. La definición de "imagen" que nos ofrece la Wikipedia es: "Una imagen (del latín imago) es una representación visual, que manifiesta la apariencia visual de un objeto real o imaginario" (https://es.wikipedia.org/wiki/Imagen, consultado el 28-III-19). La primera acepción del término "imagen" que nos ofrece el Diccionario de la Real Academia es: "imagen: Del lat. imāgo, -ĭnis. Figura, representación, semejanza y apariencia de algo." Las dos primeras acepciones del término "imagen" que nos ofrece Diccionario Espasa-Calpe son: "imagen: Figura, representación de una persona o cosa: imagen de la diosa Cibeles"; "Representación mental de algo: tienes una imagen equivocada de él." Dado que el diccionario nos remiten a la noción de "figura", veamos cómo define esta palabra: el Diccionario de la Real Academia dice: "Del lat. figūra. Forma exterior de alguien o de algo" (1ª acepción), y "Cosa representada pictórica o escultóricamente. Un pañuelo con figuras de colores" (4-a acepción). En el Espasa-Calpe podemos leer: "Forma exterior de un cuerpo: ese cuadro tiene figura oval" (1a acepción) y "Estatua o pintura que representa el cuerpo de un hombre o animal: guarda sus figuras de porcelana en una vitrina" ( $2^{\underline{a}}$ acepción).

Umática. 2018; 1: 57-104 
of" something else" (Mitchell, 1995: 11), sino que se sirve de las imágenes como modelo privilegiado para explicar qué es una de representación (12-14), a pesar de tratarse de un manual de teoría literaria destinado a ofrecer a los estudiantes una comprensión de las obras literarias como prácticas culturales. Se refiere a ellas, por ejemplo, cuando, para ilustrar restricciones que pueden pesar sobre las representaciones, menciona expresamente "Taboos against graven images", señalando que "Pornography provides the most interesting examples of all these attempts to limit the triangle of representation", indicando que las fotografías y las películas obscenas ("dirty") suelen ser sometidas a prohibiciones más estrictas que los libros obscenos (15).

Pasemos ahora al alcance de las palabras "siempre" y "es" en la frase "¿tiene que ser siempre cierto que una imagen es una representación?" Considerando lo dicho, podría parecer que el sentido de la pregunta es: ¿podríamos afirmar que todas las imágenes son representaciones? o, expresado de otra forma, ¿existe la posibilidad de que haya imágenes que no son representaciones? Este planteamiento entraña un malentendido. En primer lugar, porque de ninguna cosa puede afirmarse "esto es una un signo" (como hemos visto en $\S 3$, "Nothing is a sign unless it is interpreted as a sign"). Y en segundo lugar - y como corolario de lo anterior ${ }^{26}$ — porque no hay nada que no pueda ser usado como representación ${ }^{27}$. Sea la que sea la cosa que escojamos (una piedra recogida del suelo al azar, un botón, un animal, cierto fenómeno atmosférico, etc.), siempre puede servir, al menos, como representación de una clase de cosas) ${ }^{28}$. Así que la cuestión acerca de si existe la posibilidad de que haya imágenes que no son representaciones es absurda o, al menos, tan absurda como la declaración "el conejo es un alimento" (sobre todo cuando se piensa en los herbívoros). La afirmación "esto es una representación (signo) de X" remite a una relación y no a una cosa, y, cuando se analiza estrictamente, se ve que una representación es algo que existe sólo, y

26. Del hecho de que "Nothing is a sign unless it is interpreted as a sign" se deriva que "Anything can be a sign as long as someone interprets it as 'signifying' something — referring to or standing for something other than itself. We interpret things as signs largely unconsciously by relating them to familiar systems of conventions." Vid. Chandler 2007: 13).

27. "La semejanza", argumenta consistentemente Goodman en Los lenguajes del arte, "tampoco es necesaria para la referencia; prácticamente cualquier cosa puede representar a cualquier otra [almost anything may stand for almost anything else]" (Goodman, 2010:21)

28. En su Teoría de la imagen, Mitchell aporta un ejemplo del hecho de que cualquier cosa puede ser empleada como representación de otra. Analizando la tesis de Goodman que postula que "El parecido o el engaño, lejos de ser fuentes y criterios constantes e independientes de la práctica representativa, son, hasta cierto punto, productos de la misma", y para ilustrar el hecho de que el parecido es un "producto" causado por la actividad representativa, y no una "precondición" de la misma, Mitchell explica lo siguiente: "Puedo usar el salero que se encuentra sobre mi mesa para representar, es decir, para denotar un hombre o una montaña, y este uso es independiente de cualquier condición previa de parecido. [...] Mientras el salero no esté siendo empleado para representar nada, su parecido con cualquier posible referente (excepto, posiblemente, otros saleros) es invisible e irrelevante. Pero tan pronto como usamos el salero para representar un hombre o una montaña, las consideraciones de parecido comienzan a emerger. Comenzamos a pensar en la parte superior como 'parecida a' una cabeza, los lados parecen el cuerpo; o imaginamos un pequeño escalador luchando por no resbalarse por la empinada pendiente." (Mitchell, 2009: 308-309). 
que sólo puede existir, en una mente. Ésta es la razón por la cual la afirmación "las imágenes no existen" tiene sentido (aunque únicamente cuando se asume la petitio principii que postula que imagen $=$ signo).

Es innegable que hay imágenes — como la imagen del corazón que consiste en la inscripción o la de Peppa Pig - cuya existencia está inextricablemente identificada con su existencia como representaciones. Han sido creadas adrede para servir como signos y, como han sido conformadas ex profeso para ser empleadas de esta forma, no es fácil imaginar otros modos de emplearlas aprovechando el modo en que han sido conformadas. Pero también hay imágenes (las tatusas) que han sido creadas ex profeso para otros propósitos, y cuyo funcionamiento y existencia no dependen del hecho de estar siendo vistas como representaciones: en el escenario post-apocalíptico imaginado por Mitchell, los señuelos abandonados a su suerte sobre las aguas del lago son tratados como patos por los patos de carne y hueso, y no como representaciones. Tampoco está como una representación la prótesis dental masticando acoplada en la dentadura de una persona, ni el avión de papel volando.

Cuando Gombrich plantea la cuestión "¿Tiene que ser siempre cierto que la cama del escultor es una representación?", la cuestión que pretende poner sobre la mesa es que hay imágenes que admiten ser usadas en empleos que no exigen contemplarlas como representaciones, y que estos son empleos que la teoría de las imágenes no puede desdeñar. Uno de los ejemplos que menciona es una imagen en bronce de un cangrejo obtenida a partir de un vaciado del natural (perfectamente naturalista, por tanto). Fue hecha en Venecia, hacia 1494, por el escultor Andrea el Riccio, que la diseñó de forma que pudiera abrirse y emplearse como tintero. Veamos qué dice Gombrich:

Tomemos cualquier objeto de un museo, por ejemplo, la Caja en forma de cangrejo de Riccio, que está en la colección Kress. Si la tuviera en mi mano, o mejor encima de mi mesa, podría muy bien sentirme tentado a jugar con ella, a hurgarla con la pluma, o a advertir a un niño (contrariamente a toda psicología) que no toque los papeles de la mesa porque si lo hace el cangrejo le morderá. ¿Y quién sabe si sus pinchantes patas y pinzas no se hicieron para esconder y proteger el contenido de la caja contra dedos osados? Dicho brevemente, encima de la mesa este objeto pertenecería a la especie cangrejo, subespecie cangrejo de bronce. Al contemplarlo en su vitrina [del museo], mi reacción es diferente. Pienso en ciertas tendencias del realismo renacentista que llevan a Palissy y su style rustique. El objeto pertenece a la especie bronces del Renacimiento, subespecie bronces representando cangrejos. (Gombrich, 2002: 96-97)

Cuando se lo aparta del uso al que estaba destinado y se lo deposita en el museo, este cangrejo es dispuesto ahí para ser usado de una forma específica: siendo contemplado como monumento destinado a rememorar la obra del escultor italiano Andrea Briosco, apodado el Riccio (Trento, c.1470 - Padua, 1532), que fue hijo del orfebre milanés Ambrosio di Cristoforo 
Briosco, se formó en el taller de su padre, aprendió el arte de la fundición en bronce con Bartolomeo Bellano, fue asistente de Donatello y es conocido por bronces en pequeño formato, a menudo objetos prácticos como tinteros, aldabas de puertas, etc., exquisitamente trabajados al estilo de la escuela renacentista de Génova del siglo XVI, influida por la obra del ceramista francés Bernard Palissy, etc. Pero, depositado sobre un escritorio, este cangrejo puede servir como bicho apotropaico, porque, re-produciendo el cuerpo de un animal que puede inspirar temor, también re-produce el temor producido por un cangrejo. (El cangrejo de Riccio también podría emplearse como pisapapeles, o como materia prima para hacer un lingote de bronce. Pero, usado de estos modos, la conformación de su cuerpo es irrelevante.)

Re-produciendo el cuerpo de un cangrejo (y, por lo tanto, también su aspecto), esta obra de Riccio puede re-producir el temor producido por un cangrejo en la persona que siente temor por los cangrejos. En la medida en que puede hacer esto, esta imagen podría hacer las veces de un cangrejo (en cierto sentido o capacidad) y, como dice Gombrich, "pertenecería a la especie cangrejo, subespecie cangrejo de bronce". Gombrich se sirve de esta fórmula categorizadora en varias ocasiones en el capítulo "El poderío de Pigmalión", de Arte e ilusión. Menciona, por ejemplo, el caso de un niño que juega usando un orinal metálico a modo de casco de acero. "En el contexto del juego", nos dice, "este último artefacto puede resultar muy adecuado a sus fines. No 'representa' un casco, es una especie de casco improvisado, e incluso puede tener realidad como tal" (Gombrich, 2002: 84). Gombrich formuló por primera vez la fórmula "pertenece a la especie X, subespecie X-imagen" en su ensayo de 1951 "Meditaciones sobre una caballo de juguete o Las raíces de la forma artística". En este ensayo clásico, nuestro autor fantaseaba acerca de los orígenes de la fabricación de imágenes sirviéndose, a modo de ilustración, de un juguete actualmente caído en desuso: el caballo de palo. La razón de ser de este juguete no es servir como representación de un caballo, sino servir como sustituto de él:

El palo no es un signo que signifique el concepto "caballo", ni es un retrato de un caballo individual. Por su capacidad para servir como "sustitutivo" [substitute], el palo se convierte en un caballo por derecho propio, pertenece al grupo de los "arre-arre" y hasta quizá puede merecer un nombre propio. (Gombrich, 1998:2)

Cuando esta imagen de un caballo es entendida como un ser que pertenece a la especie "arre-arre", subespecie "arre-arre de palo", su relación con un caballo no es la de un signo, y tampoco es de "parecido", sino de "equivalencia". Algo "representa" a otra cosa cuando, en algún aspecto o capacidad, "funciona" de la misma manera: el caballo de juguete —un paloes un caballo porque es cabalgable. Esta modalidad de sustitución se da tanto en las personas como en los animales. El gato persigue una pelotita como si fuera un ratón. Un bebé chupa su dedo como si fuera el pezón materno. Lo que aquí resulta crucial no es tanto la semejanza formal ("más allá de los requerimientos mínimos de la función") como el hecho de que pueda ser empleada de una forma funcionalmente semejante: la pelotita rueda y salta 
al tropezar con algo, así que es perseguible; el dedo cabe en la boca y es chupable, así que puede aliviar siendo succionada como el pecho materno.

Como "sustitutivos" — explica Gombrich—, cumplen ciertas demandas del organismo. Son llaves que, como por azar, encajan en cerraduras biológicas o psicológicas, o son monedas falsas que hacen funcionar la máquina cuando se las echa por la ranura. (Gombrich, 1998: 4)

\section{$\S$ 5.1. Muñeca de Crepereia = ser perteneciente a la especie mujer, subespecie mujer de marfil}

En lo que acabamos de ver hay tres importantes ideas básicas que deseamos destacar antes de pasar al apartado siguiente. Que las imágenes no siempre son empleadas como signos, ya que algunas pueden servir siendo usadas fácticamente como "sustitutos". Que hay imágenes que, de alguna manera, pueden funcionar como llaves que, encajando en cerraduras biológicas o psicológicas, hacen funcionar mecanismos fisiológicos (= físicos) y/o mentales. Que la muñeca de Crepereia podría ser categorizada como "ser perteneciente a la especie mujer, subespecie mujer de marfil". Estas ideas, incipientemente esbozadas en "Meditaciones sobre un caballo de juguete", fueron desarrolladas por Gombrich en otros trabajos. En "El poderío de Pigmalión" (confundiendo la Historia del Arte con la historia del progreso en el arte de producir imágenes del tipo que estamos comentando), el autor de Arte e ilusión explica:
La historia del arte [...], puede describirse como un forjar llaves maestras para abrir misteriosas cerraduras de nuestros sentidos, para las cuales sólo la pro- pia naturaleza tenía originariamente la llave. Son cerraduras complejas, que sólo responden cuando se empieza por poner en debido estado varios tornillos y cuando varios pestillos se mueven a la vez. Como el ladrón que intenta for- zar una caja de caudales, el artista carece de acceso directo al mecanismo in- terior. Sólo puede tantear con dedos sensibles, ensayando y ajustando la gan- zúa o su alambre cuando algo cede..
En la historia del arte se dan invenciones que tienen algo del carácter de tal "ábrete sésamo". [...] No se trata de debatir si la naturaleza "se parece real- mente" a esos artificios pictóricos, sino de si esos cuadros con tales rasgos sugieren una lectura en términos de objetos naturales. (Gombrich, 2002: 304)

Uno de los trabajos donde Gombrich ha desarrollado las tres importantes ideas básicas que acabamos de destacar es un ensayo titulado "Escultura para exteriores", incluido en Los usos de las imágenes. Aquí, comentando un escrito de Baudelaire ("Pourquoi la sculpture est ennuyeuse" ["Por qué la escultura es tan aburrida"], 1846) donde el poeta contrapone la escultura a la pintura -identificando la primera con un arte primitivo propio de "caribeños" y la segunda con arte civilizado e intelectualmente superior-, nuestro autor rememora su ensayo Umática. 2018; 1: 57-104 
"Meditaciones sobre un caballo de juguete" para hacer una observación (también apuntada por Bettini) que aclara un aspecto importante del tipo de imagen que es una muñeca: entre las imágenes bidimensionales y tridimensionales de un caballo existe una diferencia crucial:

[E]l dibujo no sería un juguete, [un niño] no podría manipularlo ni mucho menos montarse en él, y por lo tanto carecería de esa peculiar carga de que está dotada una imagen en tres dimensiones. (Gombrich, 2003: 138-139)

A continuación, Gombrich retoma la afortunada comparación del funcionamiento de las imágenes empleables como juguetes con el del funcionamiento del mecanismo llave/cerradura ${ }^{29}$ y, sirviéndose del oso de peluche como ejemplo, declara: "Seguramente sería utilizar mal el lenguaje decir que la función del oso de peluche es representar un oso. No es así. Es un nuevo tipo de oso." (Gombrich, 2003: 139). Después de referir que algunos de los primeros osos de peluche fabricados el siglo pasado han acabado siendo expuestos como objetos museográficos, y se han convertido en cotizados objetos de coleccionismo, aún añade:

Pero lo que puede denominarse estetización o esterilización del oso de peluche se produjo unos pocos siglos después de la estetización de los cuadros de santos. Seguramente la demanda original del oso no era la demanda de una obra de arte, sino de una criatura para jugar, un compañero con el que el niño compartiera la almohada o el plato; en otras palabras, para resultar investido de una especie de alma. Es difícil encontrar una palabra para describir esta capacidad de las imágenes tridimensionales de ser atraídas al mundo de los vivos, de convertirse no en representaciones de otra cosa sino casi en individuos por derecho propio. La palabra "personalizado" podría ajustarse a ello sin no se hubiera abusado tanto de ella. Quizá la de "animación" es la que mejor

29. El recurso al mecanismo llave-cerradura como símil para explicar el funcionamiento "natural" de ciertas imágenes ha sido asumido por Umberto Eco, quien, tras décadas de negar rotundamente el "fenómeno del iconismo" [ver nota 15], en Kant y el ornitorrinco admite la existencia de un "iconismo primario". "[E]l icono", explica Eco, "es la disponibilidad natural de algo a ensamblarse con otro algo. [...] No estoy repudiando en absoluto la distinción (que sigue siendo basilar) entre señal y signo, entre procesos diádicos de estímulo-respuesta y procesos triádicos de interpretación [...]. Estoy admitiendo, sin embargo, [...] que existen unas 'bases materiales de la significación', y que estas bases están precisamente en esa disposición al encuentro y a la interacción que podemos ver como la primera aparición (todavía no cognitiva y desde luego no mental) del iconismo primario. [...] Eliminemos de este contexto la palabra 'signos' [...], queda el hecho de que, en la situación citada, dos algos se encuentran porque son adecuados el uno para el otro como el tornillo es adecuado para la tuerca. [...] El enzima explora la realidad y encuentra lo que corresponde a la propia forma: es una cerradura que busca y encuentra su propia llave. En términos filosóficos, un enzima es un lector que 'categoriza' la realidad determinando el conjunto de todas las moléculas que pueden reaccionar factualmente con él... Esta semiótica (o protosemiótica) es la base característica de toda la organización biológica [...]. Una vez más, me abstendría de usar términos como "signo", pero es indudable que, ante esta cerradura que busca la propia llave, estamos ante una proto-semiótica." (Eco, 1999: 125-127) 
se pueda encontrar. [...] Creo que esta extraña dualidad está siempre potencialmente presente en cualquier escultura tridimensional de exteriores que todavía no haya sido estetizada. Además, sin este telón de fondo no podemos comprender la demanda de lo que denomino escultura de exteriores en mayor medida de lo que podemos entender la demanda de muñecos para el interior de la guardería (Gombrich, 2003: 139).

La manipulación y la animación van de la mano. (Gombrich, 2003: 139-140, 144).

Suponemos que este espléndido pasaje de Gombrich podrá valer como recapitulación de las cuestiones más importantes tratadas en este trabajo hasta ahora y como preludio de las que vamos a ver a continuación.

\section{§6. El sueño atávico de la muñeca haciéndose realidad}

Bettini concluye su ensayo sobre la muñeca de la infortunada Crepereia con estas palabras: "Ahora se descubre que sus ojos estaban desesperadamente cerrados; y expresan melancolía." Emulando a Bettini, podríamos comenzar este epígrafe con una frase (ciertamente menos poética) que declarara que ahora mismo ya hay muñecas cuyos ojos están abiertos, parpadean y ostentan una mirada está cargada de porvenir.

El sueño de la muñeca viviente es ancestral, más antiguo que la transcripción textual de la llíada (probablemente manuscrita hacia la segunda mitad del siglo VIII a. C.), donde se re-

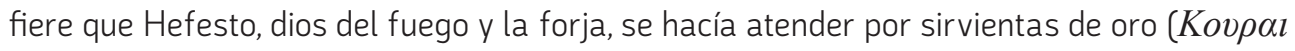
X $\rho \sigma \varepsilon \alpha l$ [Kourai Khryseai], "doncellas doradas") "parecidas a muchachas con vida", que "Tienen sentido en sus entrañas y, así mismo, tienen fuerza y voz y [...] son duchas en artísticas labores" (Homero, llíada: XVIII, 409-424). También Pandora — de quien Hesíodo dice que "desciende la estirpe de las mujeres" (Teogonía, 590) - fue una autómata salida de las manos de Hefesto.

La historia de la pretensión de crear cuerpos humanos animados es vieja. Aparece en relatos mitológicos donde una imagen de barro es animada por el dios del Génesis o por el Titán Prometeo. La encontramos en las viejas historias sobre Pigmalión, el legendario rey de Chipre, y en las modernas biografías de Descartes que afirman que éste construyó un autómata con la forma de su hija Francine. Y si Pigmalión soñó que su muñeca cobraba vida inspirado por Venus, Philip K. Dick concibió androides que soñaban con ovejas eléctricas inspirado por los avances del conocimiento científico.

El relato sobre una muñeca viviente más popular es el de la imagen de marfil esculpida por Pigmalión, conocido, sobre todo, a través del edulcorado, erótico y misógino cuento incluido por Ovidio en el libro X de sus Metamorfosis (238-297). Merece la pena llamar la atención sobre el hecho de que el propósito de Pigmalión en este cuento no es copiar a una mujer real, sino hacerse una ex novo. El rey de Chipre vivía solo y sin compañera de lecho porque des- 
preciaba a las mujeres y se sentía "ofendido por los vicios que en gran número la naturaleza dio al alma femenina". Lo que él pretendía era hacerse un espécimen de otro género de mujer, de un género artificial de mujer que, de alguna manera, fuera a las mujeres de carne y hueso lo que una planta artificial es a una planta real. Considerado el asunto desde cierto punto de vista (uno prosaicamente pragmático), una planta artificial podría resultar preferible a una real. Si únicamente se espera de ella que sirva como elemento decorativo destinado a alegrar la vista con su presencia, una planta artificial escrupulosamente hecha y de aspecto hermoso posee ventajas como las siguientes: no precisa ser regada ni requiere ser atendida por alguien que se ocupe especialmente de ella, sus hojas son inmunes a los parásitos y no se mustian con el cambio de las estaciones, siempre conserva la apariencia atractiva del primer momento, etc. Sucede lo mismo con una prótesis dental. Siendo cierto que es un artefacto comúnmente destinado a reponer una pieza dental malograda, con el propósito de restaurar la anatomía maxilar, también es verdad que tanto en la actualidad como en tiempos pasados también se han utilizado para sustituir dientes por razones de otra naturaleza: conseguir una dentadura más blanca, unos dientes alineados a la perfección y sin ningún tipo de desgaste, más resistentes, inmunes a las caries, etc. En cierto sentido, poco más es lo que el protagonista de la película de Luis García Berlanga Tamaño natural (1973) esperaba de su muñeca Camile importada de Japón — salvo, quizá, su disponibilidad para prestarse a las manipulaciones que pudiera efectuar con su cuerpo y que, de alguna manera, le hiciera sentirse acompañado ${ }^{30}$. El personaje no deseaba que su muñeca fuera una mujer real, una especie de "segundo Crátilo" platónico, sólo esperaba de ella que le sirviera en determinados aspectos o capacidades como una mujer. ${ }^{31}$ (Naturalmente, aquí no podemos entrar a considerar las implicaciones morales involucradas por un asunto tan sensible como éste.)

30. La escritora feminista Anna Krugovoy Silver se refiere a las esposas ciborg de un modo parecido en un ensayo titulado "The Cyborg Mystique: 'The Stepford Wives' and Second Wave Feminism" - que es una crítica a la película de Frank Oz The Stepford Wives (2004) protagonizada por Nicole Kidman, cuyo planteamiento es alineado por esta autora con ciertas tendencias del feminismo estadounidense de entonces (y que es la segunda adaptación cinematográfica de la novela de Ira Levin The Stepford Wives (1972 [traducida al español en 2004 por Francisco Reina Alcántara como Las mujeres perfectas]). En su ensayo, Silver describe las "esposas robot" calificándolas de "superhousewives" y señalando algunas de sus "ventajas" respecto de las mujeres de carne y hueso: "separated from all human physiological processes, do not menstruate and cannot have children" (Silver, 2002: 70), "the robots enact, in grotesque exaggeration, the cultural desire to keep the body in perfect discipline. Machines, after all, are much more easily shaped and maintained than human bodies [...] Joanna's robot double has much larger breasts than Joanna does, and they stand straight up as if surgically altered — the robot will, apparently, never grow old, never suffer from 'sagging flesh'" (Silver, 2002: 72). Silver subraya que, en términos de ocupaciones sexuales, estas esposas robóticas son diseñadas para que deseen complacer a sus esposos: "As Charmaine says [...] '/ want to please him now"' (Silver, 2002: 72). Son muchos, por supuesto, los autores que se han ocupado del asunto y que ven las muñecas sexuales como realizaciones de una compresión patriarcal y cosificadora de la mujer. Especialmente controvertido es el ensayo "A Cyborg Manifesto" publicado por Donna Haraway en 1985; vid. en capítulo "Manifiesto para cyborgs: ciencia, tecnología y feminismo socialista a finales del siglo XX" (Haraway, 1995: 251-312)

31. Además de este clásico de la historia del cine dirigido por un director español, son muchas las películas que tratan el tema de la muñeca usada como partner. Una referencia cinematográfica muy temprana la en-

Umática. 2018; 1: 57-104 
En su ensayo, Bettini menciona los autómatas y recuerda a Olimpia, la "muñeca/señorita" del cuento El hombre de arena de E. T. A. Hoffmann (1817). Refiriéndose a los productos de la téchne mechaniké, asegura que ésta "puede como mucho crear figuritas que recorren el escenario guiadas por una cinta, o sigilla que, a intervalos regulares, beben agua encima de un reloj hidráulico. Pero, evidentemente, no consigue que un muñeco se mueva o accione" (33-34). Bettini se equivoca. Dado que una muñeca es un espécimen artificial de mujer, a medida que la tecnología progresa, a la muñeca se le pueden incorporar nuevas prestaciones. Por ejemplo, aplicaciones anatómicas más ergonómicas y sofisticadas, sensores para reaccionar al ser tocadas, dispositivos para mantener una temperatura corporal semejante a la del cuerpo humano, la capacidad de moverse autónomamente (es decir, de estar realmente animada) y la posibilidad de mantener una conversación inteligente.

Hace tiempo que disponemos de robots que fabrican nuestros automóviles, limpian nuestras casas y hacen nuestra comida. Ahora hay empresas que compiten entre sí ofreciendo muñecas pigmaliónicas destinadas a servir de compañía y a proporcionar "diversión privada". Hoy parece innegable que los avances en robótica (mecatrónica), unidos a los progresos en la Inteligencia Artificial (que permiten replicar operaciones que se consideran propias de la inteligencia humana, como el razonamiento y el reconocimiento visual y del habla automáticos), cuando son aplicados a los productos de las viejas artes de producir imágenes destinadas a servir como muñecas, pueden producir autómatas capaces de comportarse "como un agente con capacidad de movimiento propio y más o menos 'voluntad"'32. Para cerciorarse de ello, basta con pensar en aplicaciones, hoy de uso común, como Siri (de Apple) o Google Assistant (de Google), el sistema Bixby Vision desarrollado por Samsung —que permite identificar objetos con la cámara del móvil—; con ojear imágenes de las muñecas "CandyGirls" producidas por la empresa japonesa Orient Industry, o algún vídeo del robot para prácticas odontológicas Showa Hanako 2, desarrollado por ingenieros de la Universidad japonesa de Showa en colaboración con Orient Industry. Showa Hanako 2 luce la conformación y el aspecto verosímiles de las muñecas sexuales producidas por Orient Industry - lo cual contribuye a crear una experiencia realista para el odontólogo en forma-

contramos en Die Puppe [La muñeca] (1919), del director de cine alemán Ernst Lubitsch. Más recientes son The Stepford Wives (1975) de Bryan Forbes, y el remake de 2004 de esta película dirigido Frank Oz referido en la nota anterior; Cherry 2000 (1987), de Steve De Jarnatt; Lars and the Real Girl (2007), de Craig Gillespie; Air Doll (2009), de Hirokazu Koreeda; la serie de televisión británico-estadounidense Humans (que es una adaptación de la galardonada serie sueca Äkta människor [Gente real]), iniciada en 2015, con guiones de Sam Vincent y Jonathan Brackley; y Sayonara (2015), de Kōji Fukada. Esta última película, que relata la relación entre una ginoide llamada Leona y Tania, una mujer gravemente enferma, es la primera película rodada con un ginoide real como protagonista. En los capítulos "Mannequins, Masks, Monster, and Dolls: Film and the Arts in the 1920 and 1930s" y "Simulated Women in Television and Films, 1940 s and After", del libro Female Robots, Androids, and Other Artificial Eves de Julie Wosk, puede encontrarse una antología interesante de películas sobre este asunto. También en las páginas 142-165 del capítulo "Do Androids Dream of Electric Orgasm?" de The Sex Doll: A History, de Ferguson Anthony.

32. Para una aproximación al estado actual de las posibilidades de la robótica aplicadas a la producción de androides y robots sexuales vid. Serrano, 2018: 183, 188 y $208-210$.

Umática. 2018; 1: 57-104 
ción. Además ha sido equipado con un programa de reconocimiento de voz que hace posible que la persona que lo manipula pueda mantener una conversación básica con él mientras lo interviene. La muñeca mueve la cabeza, puede imitar expresiones de una persona y es capaz de "sentir" las manipulaciones que se hacen dentro de su boca y reaccionar a ellas parpadeando, bostezando, tosiendo e incluso con gestos de ahogo. ${ }^{33}$ Todo esto contribuye a reforzar la propensión empática que induce a atribuir emociones humanas a la muñeca, sumándole el denominado "efecto Eliza" (tendencia a asumir que ciertos comportamientos de las máquinas son análogos a los comportamientos humanos a pesar de saber que no son humanos). Otro caso, quizá más popular, es el de la ginoide Sophia, desarrollada por la compañía Hanson Robótics, que cuenta con un sistema de aprendizaje que le permite entablar conversaciones "sesudas" con su interlocutor, y que, de hecho, ha sido entrevistada por todo el mundo. Ha sido diseñada para aprender y adaptarse al comportamiento humano, de forma que pueda trabajar con personas. En octubre de zo17 le fue concedida la ciudadana saudí, siendo el primer robot con ciudadanía de un país.

Las muñecas ginoides actuales distan mucho de ser los modelos Nexus-6 creados por la Tyrell Corporation de la película Blade Runner (cuyo motto es "More human than human") o la Ava de Ex Machina. No obstante, los autores de Robot Sex: Social and Ethical Implications responden la pregunta "Do Any Sex Robots Exist Right Now?" contestando: "The simple answer is "yes" - with the caveat that those in existence right now are relatively crude and unsophisticated." (Danaher \&t McArthur, 2017: 6). A continuación analizan dos modelos, uno de ellos es el ginoide "Harmony" producido por la empresa RealDoll, que promociona este producto calificándolo "The Perfect Companion". Se trata de una muñeca hiperrealista y articulada de látex, a la cual se le ha incorporado una cabeza robótica provista de Inteligencia Artificial y un rostro capaz de gesticular. Esto permite a la muñeca mantener una conversación, hacer chistes e incluso recordar datos obtenidos de conversaciones anteriores. Otras empresas están desarrollando robots con habilidades motrices asombrosamente similares a las humanas o a las de algunos animales. Boston Dynamics es probablemente la más conocida (su anonadantes vídeos promocionales pueden consultarse fácilmente en internet). Aunque aún estamos lejos de producir androides dotados de Inteligencia Artificial avanzada que integren estas características motrices en imágenes dotadas de una apariencia y un tacto similares a los humanos, el sueño milenario de crear un ser artificial para usarlo como compañero, compañero sexual o ambas cosas parece estar al alcance de la mano. Según el experto en inteligencia artificial David Levy,

Aceptando que hacia 2050 se habrán dado unos enormes avances tecnológicos, mi tesis es ésta: los robots serán muy atractivos para los seres humanos como compañeros por sus muchos talentos, sentidos y capacidades. Tendrán

33. Para una descripción de las prestaciones del robot para prácticas odontológicas Showa Hanako 2 puede consultarse encontrase la página https://phys.org/news/2011-06-showa-hanako-realistic-robot-novice.html. Puede accederse a un vídeo promocional en https://www.youtube.com/watch?v=WhzbFaNueKU. 
la capacidad de enamorarse de los seres humanos, de atraerlos románticamente y de despertar deseo sexual. (Levy, 2007: 34-35)

En su libro Amor y sexo con robots, Levy pronostica que dentro de 30 años las personas tendrán relaciones íntimas con robots - no solo sexo, también relaciones de amistad, amorosas y matrimoniales. Un aspecto importante de estas predicciones (y de otras semejantes), así como de las controversias generadas por ellas, es el hecho de que estas imágenes animadas (y también los equivalentes masculinos de las mismas) no son pensadas como representaciones. En vez de como signos que remiten a otra cosa, estos muñecos son pensados como "sustitutos" o, si se quiere, como miembros artificiales del género humano. Por ejemplo, al mismo tiempo que los ingenieros están desarrollando robots sexuales dotados de Inteligencia Artificial cada vez más convincentes — con la pretensión de hacerlos "más humanos" y, por tanto, más atractivos para los clientes-, también se desarrollan campañas contra estos desarrollos tecnológicos. Pero aunque los partidarios y los detractores de estas imágenes robóticas están claramente enfrentados en su valoración de estos nuevos juguetes sexuales, ambos coinciden en un punto. Cuando Kathleen Richardson (la profesora de Ética, Cultura robótica e Inteligencia Artificial de la Universidad de Monfort en Leicester, que en 2015 fundó "The Campaign Against Sex Robots") afirma que los robots sexuales deben ser prohibidos, los define como "[machines] in the form of women or children for use as sex objects, substitutes for human partners or prostitutes", es decir, los define como "sustitutos" de compañeros (partner) o prostitutas humanos. La comprensión de los partidarios de estas imágenes es la misma, también las ven como sustitutos que "no tienen por qué ser réplicas mecanizadas de mujeres de carne y hueso", aunque "podrían ayudar a eliminar el factor de explotación [sexual] que existe ahora"34.

34. Puede encontrarse una referencia a los dos enfoques contrapuestos comentados aquí en la crónica periodística de Carlos Fresneda a la segunda edición del International Congress on Love and Sex with Robots, que tuvo lugar tuvo lugar en diciembre de 2016 en la Universidad Goldsmiths de Londres (Fresneda, 2017). En este congreso, la profesora de esta universidad especializada en la interacción de los seres humanos con la tecnología Kate Devlin señaló que "El sector sex tech mueve ya al año más de 30.000 millones de dólares y el boom no ha hecho más que empezar", afirmó que "hacer el amor con una máquina no es una conducta desviada sino algo cada vez más normal", y auguró que aunque el sector sex tech ha estado dominado tradicionalmente por hombres, que han impuesto su visión de la mujer objeto, el peso de las mujeres en esta industria está empezando a ser cada vez más relevante. También defendía un empleo "terapéutico" de los robots: "Ya se utilizan robots como asistentes médicos y sociales, o para procurar compañía. El siguiente paso sería que sirvieran también de compañeros sexuales en casos de personas especialmente aisladas o discapacitadas, o de hombres y mujeres que han perdido al amor de su vida".

Umática. 2018; 1: 57-104 


\section{§ 6.1. "What Do You Mean, 'It's Just Like a Real Dog'?"}

Sherry Turkle es profesora de Psicología social en el Instituto de Tecnología de Massachusetts y está especializada en los efectos de los mundos digitales en el comportamiento humano. En una entrevista realizada el año 2000 , donde respondía a preguntas relacionadas con la actitud de los niños frente a las muñecas y las mascotas robóticas que empezaban a invadir el mercado de los juguetes - y que cada vez más parecían estar vivos-, la entrevistadora se interesó por cuál era la comprensión de lo viviente de los niños ["What do children think about what it means to be alive?"], ya que algunos de estos juguetes, no sólo simulan vivir, sino que también "se mueren".35

Entre las mascotas "no biológicas" referidas en la conversación, se mencionaban juguetes electrónicos como los Tamagotchis y los Furbies. A diferencia de la muñeca de Crepereia y el osito de peluche de comentado por Gombrich, un Furby un es muñeco que no imita el aspecto de un animal conocido, y funciona sin tener que ser manipulado. Se lo describe como un peluche con un aspecto híbrido que combina rasgos de ratón, gato, murciélago y búho. Es un juguete provisto de sensores que permiten que gesticule y mueva la lengua cuando se le da de comer. También está provisto de Inteligencia Artificial, y no sólo puede hablar, sino que también puede desarrollar su capacidad lingüística. Empieza hablando Furbish, un lenguaje muy básico y pobre que cada uno de estos juguetes trae instalado de serie. Pero estas mascotas artificiales, que están equipadas con un sistema de reconocimiento de voz, han sido programadas de forma que, a medida que se interactúa con ellas, van aprendiendo el idioma en el que se les habla siguiendo una pauta que imita el proceso de aprendizaje natural de una lengua.

Cuando la entrevistadora se interesó por la investigación sobre la interacción de los niños con los Furbies que Turkle estaba realizando, la investigadora respondió que su colaboradora Jennifer Audley había preguntado a los niños una y otra vez "¿Está vivo? ¿Es como una verdadera mascota? ¿Te conoce?" A menudo la respuesta fue "No está vivo de una manera humana o animal, pero si de una manera Furby" ["It's not alive in a human or animal kind of way, but in a Furby kind of way"]. La profesora glosaba esta respuesta comentando que, cuando una muñeca fabricada diez años antes decía: "Te quiero", los niños sabían que el sonido procedía de una pequeña grabadora situada en el interior de la muñeca, y que era una frase mecánica y no una respuesta surgida de una conciencia que sentía afecto por la persona que cuidaba de ella. Pero a continuación señalaba que estaba surgiendo una clase de muñecos específicamente diseñados para provocar exactamente este tipo de respuesta.

En la entrevista se mencionan otros juguetes, todavía más sofisticados que los Furbies, donde el deslinde de lo animado y lo animado se desdibuja aún más. Se refieren también mascotas artificiales específicamente destinadas a proporcionar compañía a personas mayores, (como el "Aibo robotic dog"), de la cuales una mujer afirmó que son mejores que un perro real, porque no te hunden en el dolor muriéndose de repente. Y aquí podría mencionarse el

35. Hafner, Katie. (25-V-2000). "What do you mean, 'it's just like a real dog'?" New York Times. http://partners. nytimes.com/library/tech/00/05/circuits/articles/25pets.html. 
caso de ese famoso nuevo Pigmalión llamado Senji Nakajima que, como el protagonista de la película Tamaño natural de Berlanga, convive una con una muñeca sexual, a la cual llama "Saori". Este japonés se ha hecho célebre haciendo pública su convivencia con su Azumagata Ningyo (吾妻形人形, "esposa sustituta", "muñeca de mujer") y proclamando el amor que siente por ella. Este hombre, que afirma que su muñeca es mucho mejor que su esposa, ha declarado "Para mí ella es mucho más que una muñeca, no es simple silicona. Ella necesita mucha ayuda, pero es mi pareja perfecta y compartimos grandes momentos juntos".

Nuestra proclividad a comprometernos emocionalmente con criaturas "ilusionistas" parece innegable. Suponemos que tanto como el hecho de que, por poderosa que sea nuestra respuesta a "imágenes no figurativas" como el "tridente imposible" ["Devil's Tuning Fork"] creado por el psicólogo D. H Schuster, o incluso a ilusiones ópticas asombrosamente "vivientes" (o, cuanto menos, animadas) como la Rotating Snakes de la profesora de psicología Akiyoshi Kitaoka, las imágenes que pueden emplearse como muñecas ostentan un superávit empático que las hace aún más poderosas. Suponemos también que ese superávit tiene que ver con eso que Gombrich no quiso llamar "personificación" y denominó "animación". Es probable que Ortega y Gasset refiriera a este fenómeno cuando en "La deshumanización del arte" (1925) habla del "asco" que le inspiran las estatuas de cera señalando:

Ante las figuras de cera todos hemos sentido una peculiar desazón. Proviene ésta del equívoco urgente que en ellas habita y nos impide adoptar en su presencia una actitud clara y estable. Cuando las sentimos como seres vivos nos burlan descubriendo su cadavérico secreto de muñecos, y si las vemos como ficciones parecen palpitar irritadas. No hay manera de reducirlas a meros objetos. Al mirarlas, nos azora sospechar que son ellas quienes nos están mirando a nosotros. Y concluimos por sentir asco hacia aquella especie de cadáveres alquilados. La figura de cera es el melodrama. (Ortega y Gasset, 1987: 33)

"No hay manera de reducirlas a meros objetos", porque, aunque sabemos que son artefactos inertes, sentimos que viven y que nos hacen responder a su presencia como si fueran "sujetos", es decir, entidades vivientes capaces de actuar sobre nosotros. Esto nos desconcierta, porque, desdibujando los límites entre lo inerte y lo viviente, arruina el concier to habitual entre lo que sabemos y lo que sentimos - y colapsa nuestra capacidad para saber a qué a-tenernos. (Las ilusiones ópticas referidas antes también nos desconciertan, pero carecen del superávit proporcionado por la "personificación").

¿No sería posible que en la fascinación involucrada por este desconcierto esté el origen de fenómenos como la agalmatofilia y la idolatría? Quién sabe. Lo que sí se sabe bien es que la expulsión de las imágenes que suscitan "asco" del ámbito del buen gusto y lo civilizado sí está directamente relacionada con ella ${ }^{36}$. Y también que es en ella donde Adorno sitúa el pu-

36. Kant emplea la palabra "asco" ["Ekel"] en un pasaje famoso del $\S 48$ de su Crítica del juicio. Se sirve de ella para [des]calificar cier to tipo de "fealdad" que tiene la virtud de malograr toda satisfacción estética y es, por tanUmática. 2018; 1: 57-104 
denda origo del arte: "el hechizo de aquello de lo que la autonomía del arte quisiera liberarse", porque "las obras de arte", explica este insigne representante de la Escuela de Fráncfort, "sólo han llegado a ser tales negando su origen. No hay que afearles como un pecado original la vergüenza de su vieja dependencia respecto de disparates, servidumbres y divertimentos una vez que han aniquilado aquello de donde surgieron" (Adorno, 2004: 11, 12) ${ }^{37}$. ¿No sería posible que el origen de la iconofobia esté en la fascinación suscitada por este desconcierto?

La rotundidad de la afirmación "No hay manera de reducirlas a meros objetos" debe matizarse. Porque, como dice Gombrich, aunque hay imágenes capaces de actuar como "llaves maestras" que pueden abrir las misteriosas cerraduras de nuestros sentidos, "No somos simples máquinas automáticas que eyectamos algo en cuanto nos introducen una moneda" - ya que, a diferencia de los animales, "tenemos lo que los psicoanalistas llaman un 'yo' que contrasta la realidad y da forma a los impulsos del ello. Por esto podemos conservar el autodominio cuando medio cedemos a monedas falsas, a símbolos y sustitutos" (Gombrich, 2002: 87). Esto es cierto. Pero también es verdad que hay imágenes frente a las cuales tenemos que hacer un gran esfuerzo de autodominio para reprimir "los impulsos del ello". Pensamos en imágenes como la fotografía de la niña hondureña Yanela Sánchez llorando mientras su madre es detenida por un agente de la Patrulla Fronteriza en la frontera sur de Estados Unidos, que ha sido elegida como la mejor fotografía del año 2019 y ha recibido el premio World Press Photo. Pensamos también, y sobre todo, en imágenes que, además, tienen la capacidad de funcionar como entidades "personificadas" capaces de hacernos sentir mirados por ellas, en imágenes que, como las estatuas de cera de las que habla Ortega y Gasset o, más aún, como los Furbies y las muñecas robóticas, no sólo estorban nuestra libertad para "reducirlas a meros objetos", sino que también estimulan y dan alas a nuestra predisposición a no "reducirlas a meros objetos", alentando esa "voluntaria suspensión de la incredulidad" ("willing suspension of disbelief") descrita por el poeta inglés Samuel Taylor Coleridge a principios del siglo XIX. Frente a entidades de esta naturaleza — que no están vivas de una manera humana o animal, "pero sí de una manera Furby"一, se incumple claramente la exigencia básica del proceso semiótico, porque "El estímulo no se pone en lugar de otra cosa, sino que provoca directamente esta otra cosa" (Eco, 1994: 23, ver nota 26) Pero el "estímu-

to, inadmisible en la esfera del buen gusto. Esta virtud sería propia de la fealdad inherente a las cosas que incluso in effigie tienen la capacidad de provocar asco: "El arte bello muestra precisamente su excelencia en que describe como bellas, cosas que en la naturaleza serían feas o desagradables. [...] [S]ólo una clase de fealdad no puede ser representada conforme a la naturaleza sin echar por tierra toda satisfacción estética, por lo tanto, toda belleza artística, y es, a saber, la que despierta asco, pues como en esa extraña sensación, que descansa en una pura figuración fantástica, el objeto es representado como si, por decirlo así, nos apremiara para gustarlo, oponiéndonos nosotros a ello con violencia, la representación del objeto por el arte no se distingue ya, en nuestra sensación de la naturaleza, de ese objeto mismo, entonces no puede ser tenida por bella." (Kant, 1991:268)

37. Adorno desarrolla esta tesis en las primeras páginas de su Teoría estética (págs. 11-25) - donde sitúa el origen del Arte en "aquello de donde surgió antitéticamente", e identifica la razón de ser del Arte con "el tabú del arte", que "prohíbe que uno se comporte de manera animal con el objeto, que uno pretenda apoderarse corporalmente de él". Este mismo argumento, aunque de un modo bien distinto, es desarrollado por Pierre Bourdieu en La distinción, a lo largo de todo el libro y de manera más específica su "Post-scriptum" (págs. 478-495).

Umática. 2018; 1: 57-104 
lo", en este caso, no es el mero y fugaz destello luminoso que nos obliga por un instante a cerrar los ojos del que habla Eco, ni tampoco una imagen que consigue captar nuestra atención de una forma más o menos persistente, porque se mueve sin moverse como las Rotating Snakes. Es una tatusa "personificada" que, en algún sentido, está insidiosa o sugestivamente viva "a la manera Furbie", y que estorba nuestra capacidad para reducirla a la condición de mero objeto - de "objeto" mansa, inerte e inermemente disponible para un "sujeto" dispuesto a interpretarlo aplicando un código semiótico.

Nos interesa llamar la atención sobre estos detalles porque deseamos contrastar las muñecas (tanto antiguas como la de Crepereia como modernas como las fabricadas por la empresa Orient Industry), los juguetes referidos por Turkle, las estatuas de cera mencionadas por Ortega y Gasset y, en general, las imágenes que suscitan la experiencia del "asco", con dos imágenes a las que nos hemos referido ya: la de Peppa Pig y la del signo del corazón que consiste en la inscripción $\$. Si no hubiera mentes humanas, las imágenes de Peppa Pig la del signo del corazón dejarían de existir. Su existencia depende de que, viéndolas, las relacionemos con otra cosa. Aplicada a estos casos, la afirmación de Mitchell "Si no hubiera mentes tampoco habría imágenes, ni mentales ni materiales" resulta incuestionable. Pero en el caso de imágenes como las muñecas robóticas, por ejemplo, nuestra relación con ellas no tiene que ser semiótica y, de hecho, cuesta que sea semiótica (como sugieren las referencias al "asco" mencionadas). Podemos verlas como representaciones que están en lugar de otra cosa, desde luego. Pero no tenemos que relacionarnos con ellas de este modo. Y lo cierto es que han sido concebidas y conformadas para resultar lo más eficientes posible siendo empleadas de otra forma.

Conocemos otros ejemplos que permiten ver, incluso de una forma más palmaria, que la existencia fáctica de todas las imágenes no depende de nuestra mente. Son imágenes cuyo funcionamiento es completamente independiente de nuestra conciencia. El avión de papel que vuela como un avión; la prótesis dental y esas otras prótesis que son la tetina del biberón y el chupete (llamado "pacifier" en inglés); el robot cuadrúpedo Big Dog, que ha sido desarrollando por la empresa Boston Dynamics para ser empleado una mula de carga y que, lo mismo que este animal puede atravesar terrenos difíciles, sortear obstáculos complicados, recuperar el equilibrio sin llegar a caerse cuando resbala, etc. (además, es menos tozudo, inmune a los gases tóxicos, no se cansa, etc.); los dummies empleados como la vaca de madera hueca que cubierta con piel de vaca que Dédalo le hizo a Pasífae para que ésta pudiera satisfacer su deseo de ser cubierta por un toro, que se utilizan para obtener de semen de animales salvajes, alpacas, etc. ${ }^{38}$; los dummies conocidos como "crash test dummies" ("maniquíes para pruebas de choque") utilizados por organismos como Euro NCAP, que son muñecos que reproducen con exactitud las dimensiones, la distribución de pesos, la estructura y la flexibilidad de las articulaciones de un humano, y están dotados de sensores para registrar las fuerzas, tanto de impacto como de desaceleración, las cargas y la resistencia, entre otros

38. Vid. Reyna, Jorge (2005): "Artificial Insemination in Alpacas", The International Camelid Quarterly, accesible en https://pdfs.semanticscholar.org/171f/a1d370c674b4e10aegdo3c1a1c71c326fdfa.pdf

Umática. 2018; 1: 57-104 
IMAGEN = ARTEFACTO CUYA RAZÓN DE SER ES SERVIR COMO UTENSILIO EN UN EMPLEO ESPECÍFICO.

- FUNCION = CAUSA FINALIS

- FORM FOLLOWS FUNCTION

» son "tatusas" - hay semejanza con seres en el mundo

» su configuración morfológica y su conformación material reproducen conformaciones o aspectos y capacidades zoomóficos y, por tanto, también æfectos producidos por los seres a los que se asemejan.

» funcionan por sí mismas, pero son utensilios hechos para ser manipulados, y esto requiere el concurso de una mente.

»su funcionamiento es extramental = no depende del concurso de una mente, pero es reforzado siendo acompañado e impulsado mentalmente.

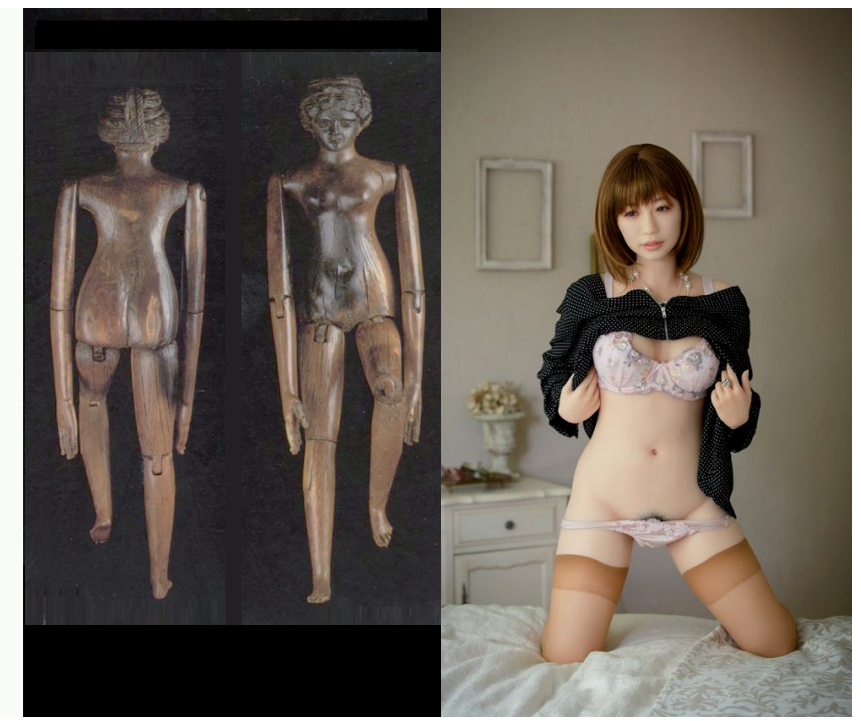

Fig. 02. valores. El funcionamiento de estas imágenes no depende de una conciencia humana. Son

Muñeca Crepereia

Tryphaenas

[s.Il d.C.]

Fig. 03 .

Muñeca sexual fabricada por Orient Industry

(2014) tatusas de las que la teoría canónica de la imagen tiene poco que decir. Aunque la relevancia, las posibilidades y el impacto en nuestro mundo de estas imágenes es cada vez mayor.

\section{§. Desenlace: "Dream dolls became physical reality"}

"Dream dolls became physical reality" es el título de uno de los epígrafes de un artículo publicado por Patrick W Galbraith hace más de diez años: "Plastic fantastic: Japan's doll industry booming" (Galbraith, 2008). Además de aportar datos sobre el auge de la industria de las muñecas sexuales en Japón y sobre la empresa Orient Industry, este artículo repasa la tradición de las muñecas sexuales en este país, y aporta datos como los siguientes: En Japón se han usado muñecos con fines religiosos y ceremoniales desde alrededor del año 1000. Esta tradición se vio enriquecida durante el período Edo (1603-1868) con una aportación llegada de manos de los marineros extranjeros: las muñecas sexuales conocidas como "dame de voyage". Se tiene constancia de la existencia de una "Azumagata Ningyo" ya en 1626. En la década de 1950, el gobierno japonés comenzó a usar muñecas sexuales para mejorar la vida de sus trabajadores en puestos remotos como el Polo Sur. A partir de aquí, el cine, el cómic y los avances de la robótica hicieron lo necesario para que la producción de este tipo de artículos se convirtiera en una industria floreciente. El resultado es que el viejo sueño de la muñeca está haciéndose una realidad física - y no sólo en Japón.

Aunque la muñeca es un tipo bastante humilde de imagen, la historia de este juguete destinado a servir de partner en juegos que exigen la manipulación de su cuerpo- es legendaria y se remonta a un pasado muy remoto. Es una narración perfumada por fantasías ancestrales vinculadas al pudenda origo del interés por las imágenes y es, también y sobre todo, un relato que actualmente parece estar abriéndose a un porvenir donde el sueño atávico de la muñeca vivificada parece estar haciéndose realidad, impulsado por los avances en robótica e inteligencia artificial. En el ámbito de la erudición académica, el locus classicus de este 


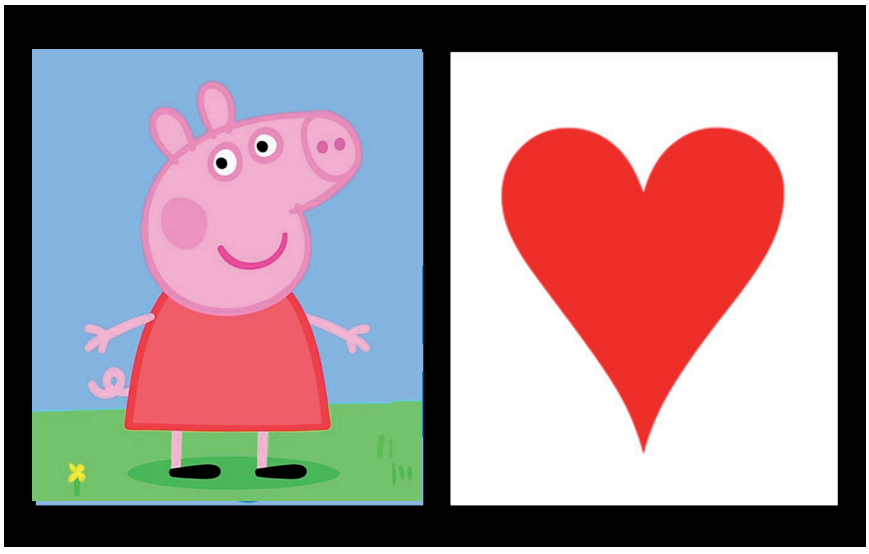

tema es el cuento de Ovidio que relata los amores de Pigmalión con una imagen de marfil que él mismo se había hecho. En este relato puede leerse que este legendario rey de Chipre obsequia con regalos a su muñeca, la dispone sobre la cama y "le habla y la estrecha entre sus brazos; se figura que la carne cede al contacto de sus dedos y teme que la presión deje algún cardenal en los miembros que ha apretado" (Las metamorfosis, libro X, vv. 258-259). Otro relato antiguo, y este histórico, refiere que la maestría de Praxíteles alcanzó fama en todo el Mediterráneo porque un joven prendado del sex-appeal de la Afrodita de Cnido tuvo relaciones sexuales con esta imagen.

Que la relación de Pigmalión con su pareja ebúrnea y la del joven enamorado de la Afrodita de Cnido con la estatua, lo mismo que la de Crepereia con su muñeca, la de los amantes de las CandyGirls manufacturadas por Orient Industry con sus "esposas sustitutas" y la de los niños con sus Furbies tienen una componente claramente mental (incluso delirante, al menos hasta cierto punto) parece obvio. Tanto como que tal relación no es semiótica ni puede ser explicada semióticamente. Sucede lo mismo, y aún más claramente, en el caso del avión de papel, las prótesis y los dummies comentados antes. La teoría canónica de la imagen no puede hacerse cargo de estas imágenes. Ni siquiera violentándolas, tildándolas de "patológicas" y descalificando a sus usuarios puede dar cuenta de ellas — porque todavía queda el resto constituido por las tatusas: prótesis, aviones de papel y dummies.

La conclusión parece obvia: la doctrina canónica de la imagen es incapaz de dar cuenta de estas imágenes. No puede hacerlo porque la premisa de la que parte (imagen = signo), no sólo es una petitio principii falaz que opera como un dogma que opera como un "punto ciego" que impide mirar lo que está ahí, frustrando la posibilidad de "salvar las apariencias" (o "los fenómenos").

Como hemos visto, aunque la teoría canónica de la imagen condena todas las imágenes a la inexistencia (y lo que la autoridad epistémica del discurso académico no menciona carece de existencia o adolece de una existencia irrelevante), las tatusas siguen ahí. Dado que en un futuro no demasiado lejano imágenes cada vez más parecidas a los androides imaginados por Philip K. Dick van a convivir con nosotros, nos conviene disponer de un conocimiento adecuado para afrontar esta situación. De hecho, los estudios acerca del modo en que nos afecta la interacción con seres que no están vivos de una manera humana o animal, "pero sí de una manera Furby" son cada vez más abundantes.

Umática. 2018; 1: 57-104
Fig. 03.

Pepa Pig

Personaje serie de animación creada por Mark Baker y Neville Astley (2004).

Fig. 05.

Signo de un corazón. 
IMAGEN = ARTEFACTO CUYA RAZÓN DE SER ES SERVIR COMO UTENSILIO EN UN EMPLEO ESPECÍFICO.

- FUNCION = CAUSA FINALIS

- FORM FOLLOWS FUNCTION

» son "tatusas" -hay semejanza con seres en el mundo

» su configuración morfológica y su conformación material reproducen conformaciones o aspectos y capacidades zoomóficos y, por tanto, también æfectos producidos por los seres a los que se asemejan.

» funcionan mecanicamente

» su funcionamiento es extramental y en absoluto requiere del con curso de una mente.

»su existencia como utensilios tiene lugar in mundus.

\section{§ g. Conclusiones}

Fig. 06. En las páginas precedentes esperamos haber demostrado que la teoría de las imágenes acPrótesis dental

Fig. 07

Avión de Papel

Fig. 08

The Bid Dog

Robot Militar diseñado por

Boston Dynamics

(2005)

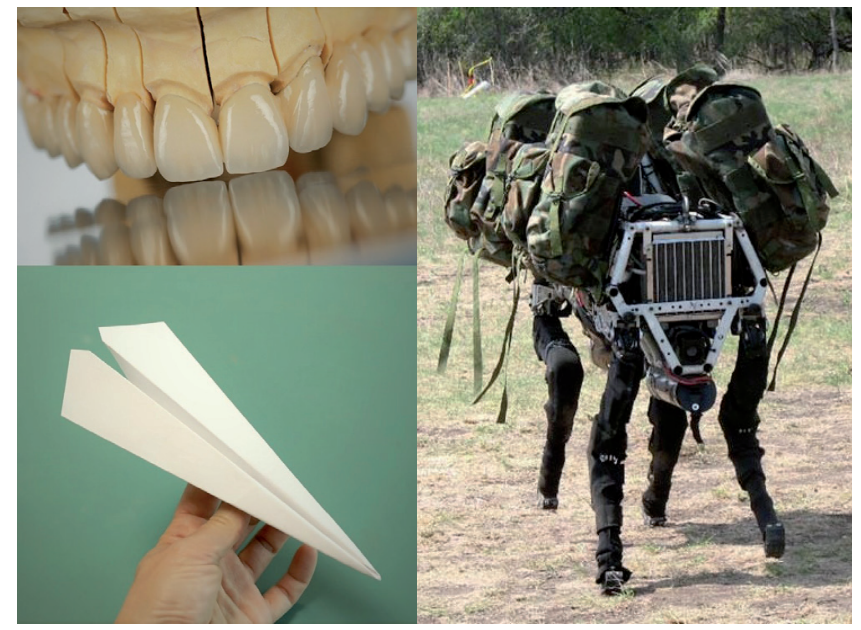
tualmente tenida por canónica adolece de dificultades y conduce a aporías. No puede aportar una definición de "imagen". Tampoco puede distinguir entre imágenes que únicamente pueden funcionar como signos (como la imagen del corazón constituida por la inscripción $\mathbf{}$ ) e imágenes que pueden funcionar sin el concurso de mente alguna (como un avión de papel, una prótesis dental, ciertas muñecas, etc.). Esta distinción nos parece importante. De hecho, aunque el enfoque convencionalista de la teoría canónica de las imágenes tiende a emborronar (agnotológicamente) la diferenciación entre imágenes y textos y niega la distinción que segrega las imágenes cuya existencia es exclusivamente mental —es decir, cuyo funcionamiento es única y exclusivamente semiótico- de esas otras que aquí hemos llamado "tatusas" - que pueden funcionar sin que su empleo dependa del concurso de una mente, aunque su funcionamiento también puede ser propulsado por una conciencia-, lo cierto es que la doctrina canónica de las imágenes parece tener muy presente la segunda de estas dos modalidades de imágenes. ¿Cómo, si no, podrían explicarse las "ansiedades" suscitadas por las imágenes tan reiteradamente referidas por Mitchell? Consideremos las siguientes declaraciones extraídas de su Teoría de la imagen:

Las ansiedades respecto al poder de la cultura visual no sólo afectan a los intelectuales críticos. Todo el mundo sabe que la televisión es mala y que su maldad tiene que ver con la pasividad y la fijación del espectador. Pero también es verdad que la gente siempre ha sabido, por lo menos desde que Moisés denunció al Becerro de Oro, que las imágenes son peligrosas y que pueden cautivar al que las mira y robarle el alma. [...] Lo que necesitamos es una crítica de la cultura visual que permanezca alerta ante el poder de las imágenes para bien y para mal, capaz de discriminar entre la variedad y especificidad de sus usos. (Mitchell, 2009: 10) 
Me gustaría sugerir que esta ansiedad, esta necesidad de defender "nuestra habla" contra "lo visual", es un síntoma claro de que está teniendo lugar un giro pictorial". Por supuesto, no pretendo decir que [...] que todas las ansiedades acerca de "lo visual" sean iguales. [... Lo que da sentido al giro pictorial no es que tengamos una forma convincente de hablar de la representación visual que dicte los términos de la teoría cultural, sino que las imágenes (pictures) constituyen un punto singular de fricción y desasosiego que atraviesa transversalmente una gran variedad de campos de investigación intelectual. (Mitchell, 2009: 20)

Por otro lado, la ansiedad respecto a la imagen, el miedo a que el "poder de las imágenes" pueda destruir finalmente incluso a sus creadores y manipuladores, es tan antiguo como la producción de imágenes misma. (Mitchell, 2009:141)

Cuando Mitchell define "imagen" mencionando (y descalificando) su identificación con "una ventana transparente al mundo", cuando se refiere a la imagen subrayando que se trata de un signo que "presenta una apariencia engañosa de naturalidad y transparencia", cuando afirma que "las imágenes son peligrosas y que pueden cautivar al que las mira y robarle el alma", cuando alude al "poder de las imágenes", cuesta pensar que lo que tiene in mente son inscripciones del tipo $\mathbf{Y}$. Imaginar que las ansiedades generadas por las imágenes son producidas por inscripciones cuyo funcionamiento es única y exclusivamente semiótico resulta bastante más difícil que pensar que Mitchell pretende meter en el mismo saco la inscripción ఛ, las prótesis dentales, los señuelos de caza y el ginoide "Harmony" producido por la empresa RealDoll (de cuya versión "Harmony 3.0" se dice que será un "sex robot with internal heating, touch sensors and self-lubricating vagina", provisto de inteligencia artificial, capaz de mantener una conversación y dotado de 10 modalidades diferentes de personalidad: tímida, sensual, celosa, mal humorada, habladora, etc.).

Nosotros entendemos que esta conceptualización de las imágenes no permite comprender las virtualidades y el interés suscitado por las "tatusas", y también que genera una teoría poco plausible de las imágenes. También pensamos que, como mínimo, deberíamos ser capaces de hacer algún tipo de distinción entre imágenes cuyo funcionamiento es única y exclusivamente semiótico (existen en la medida en que son interpretadas) e imágenes que pueden funcionar sin que su empleo dependa del concurso de una mente. La afirmación de Gombrich "Todo arte es 'producción de imágenes', y toda producción de imágenes está enraizada en la creación de sustitutivos [substitutes]" (Gombrich, 1998: 9), extraída de su contexto, suena excesiva - ya que, o bien no da cuenta de imágenes como $\boldsymbol{Y}$, o bien lleva a tener que admitir que, aunque no muerda, la palabra "perro" vale como un sustituto de un perro. Sin embargo, la idea de que una de las motivaciones más poderosas de las artes destinadas a producir imágenes (capaces de generar ansiedades) es el deseo de generar artefactos conformados de modo que puedan ser empleados como sustitutos no puede ser desestimada. Y esta idea sugiere una aproximación a las imágenes y al conocimiento de las mismas que Umática. 2018; 1: 57-104 
parte de un enfoque alternativo al de la teoría canónica de las imágenes. Gombrich lo expresó así en un ensayo de 1953 titulado "El psicoanálisis y la historia del arte":

En realidad, querría hacerles volver a Pigmalión, el mítico artista que hizo la figura de una mujer o, mejor dicho no una figura, sino una mujer. Pues ya saben [...] que en esos crepusculares comienzos del arte, un símbolo no se percibe como símbolo. El muñeco de la niña no es una imagen de un niñito tanto como un elemento de la clase "niñito", claro que con tal que se pueda hacer con él lo que se hace con los niños, abrazarlos, bañarlos y tirarlos al suelo. La estatua de Pigmalión, podemos suponer, era una mujer en el sentido en que el muñeco es un niño: tenía suficientes característica de su sexo para poder ser clasificada como una mujer. (Gombrich, 1998b: 34)

Dado que las imágenes importan y, subsiguientemente, que el conocimiento sobre las imágenes es importante, y considerando la proliferación en nuestro mundo de modalidades cada vez más poderosas e inéditas de imágenes —unas modalidades que, rebasando el ámbito de los mass media, exceden la mera incidencia de las imágenes en la opinión pública y cada vez más van a tener una incidencia mayor en nuestro mundo (realidad virtual, realidad aumentada y, sobre todo, prótesis, androides, ginoides y animales robóticos, etc.)—, urge disponer de una comprensión científicamente solvente de las imágenes. Una comprensión sine ira et studio que permita describir y explicar TODOs los empleos de las imágenes y, por tanto, capaz de dar cuenta de TODAS las imágenes.

Cuanto más afecten a nuestra experiencia nuevas formas de imagen, con mayor urgencia se planteará la vieja pregunta "¿Qué es una imagen?" Frente a este desafío, el planteamiento de Gombrich nos parece claramente más útil que el de Mitchell. Porque, antes que el "'representational animal,' homo symbolicum" del que habla Mitchell, somos una criatura viviente que actúa e interactúa con su entorno, en cuerpo y alma. Goethe hizo que el protagonista de Fausto reformulara el versículo bíblico "En el principio era el Verbo" (Juan 1, 1) escribiendo "En el principio era la Acción" ("Im Anfang war die Tat"). Parece obvio que la teoría de las imágenes necesita ser objeto de una reformulación en este mismo sentido. Porque las imágenes son artefactos destinados a ser usados como útiles, es decir, a ser accionados como utensilios, a ser empleados (puestos a trabajar) haciéndoles cosas, haciéndonos cosas con ellos, haciéndolos hacer cosas. 


\section{Bibliografía}

Adorno, Theodor W. (2004): Teoría estética. Obra completa, 7. Madrid: Akal.

Arnheim, Rudolf (1986); Hacia una psicología del arte. Arte y entropía (Ensayo sobre el desorden y el orden). Madrid: Alianza

Bell, Clive (1914): Art. New York, U.S.A.: Frederick A. Stokes Co.

Berger, Peter L. \& Luckmann, Thomas (2003). La construcción social de la realidad. Buenos Aires: Amorrortu

Bettini, Maurizio (2015); "Pupa. La muñeca en la cultura griega y romana" en Muñeca. Madrid: Casimiro, págs. 15-43

Bourdieu, Pierre (1998): La distinción. Criterio y bases sociales del gusto. Madrid: Taurus

Chalmers, Alan F. (1993 [1982, 1984]); ¿Qué es esa cosa llamada ciencia? Una valoración de la naturaleza y el estatuto de la ciencia y sus métodos. Madrid: Siglo XXI

Chandler, Daniel (2007 [2002]): Semiotics. The basics. London, New York: Routledge

Clemente de Alejandría (1994). Protréptico. Madrid: Gredos

Cruz Revueltas, Juan Cristóbal (2009): Imagen: ¿signo, icono o ídolo? De la imagen a la representación política. México, D.F.: SigloXXI

D'Ambra, Eve;"Beauty and the Roman female portrait", en J. Elsner \& M. Meyer (Eds.) (2014): Art and Rhetoric in Roman Culture, Cambridge: Cambridge University Press; 155-180

Danaher, John \& McArthur, Neil (2017): Robot Sex: Social and Ethical Implications. Cambridge, Massachusetts: The MIT Press

Debray, Régis (1994); Vida y muerte de la imagen. Historia de la mirada en Occidente. Barcelona: Paidós

Dolansky, Fanny (2012), "Playing with Gender: Girls, Dolls, and adult Ideals in the roman World", en Classical Antiquity $31(2) ; 256-292$

Eco, Umberto (1994): Signo. Barcelona: Labor

Eco, Umberto (1995): Tratado de Semiótica General, Barcelona: Lumen

Eco, Umberto (1999): Kant y el ornitorrinco. Barcelona: Lumen

Elkins, James (2001 [1999]); The domain of images, New York: Cornell University Press

Elkins, James \& Naef, Maja (ed.) (2011): What Is an Image? Vol. 2 de Stone Art Theory Seminars. Pennsylvania: University Park, PA: Penn State Press

Elkins, James (2010): "Un seminario sobre teoría de la imagen", en Estudios Visuales 9 (http://www.estudiosvisuales. net/revista/pdf/num7/og_elkins.pdf)

Ferguson, Anthony: (2010). The Sex Doll: A History. Jefferson, North Carolina y London: McFarland \& Company, Inc., Publishers

Freedberg, David (1992): El poder de las imágenes. Estudios sobre la historia y la teoría de la respuesta. Madrid: Cátedra

Fresneda, Carlos (2017); "Hablemos de sexo (con robots)", Diario el Mundo, 11-II-2017 (https://www.elmundo.es/ cronica/2017/02/11/5895c78ee5fdeaeg5f8b4630.html)

Galbraith, Patrick W. (2008): "Plastic fantastic: Japan's doll industry booming", originalmente publicado en Metropolis magazine (22-2-2009), y actualmente accesible en Japan Today: Japanese News and Discussion (https://japantoday.com/category/features/lifestyle/plastic-fantastic-japans-doll-industry-booming)

Goodman, Nelson (1990); Maneras de hacer mundos. Barcelona: Visor

Goodman, Nelson (2010); Los lenguajes del arte. Una aproximación a la teoría de los símbolos. Madrid: Paidos

Umática. 2018; 1: 57-104 
Gombrich, Ernst H. (2002 [1998]): Arte e ilusion. Estudio sobre la psicología de la representación Pictórica, Madrid: Debate

Gombrich, Ernst H. (1998) "Meditaciones sobre un caballo de juguete", en Meditaciones sobre un caballo de juguete. Yotros ensayos sobre la teoría del arte. Madrid: Debate, págs. 1-11

Gombrich, Ernst H. (1998b) "El psicoanálisis y la historia del arte", en Meditaciones sobre un caballo de juguete. Y otros ensayos sobre la teoría del arte. Madrid: Debate, págs. 30-44

Gombrich, Ernst H. (2003): Los usos de las imágenes. Estudios sobre la función social del arte y la comunicación visual. Barcelona: Debate

Gubern, Román (2004): Patologías de la imagen. Barcelona: Anagrama

Haraway, Donna (1995): Ciencia, cyborgs y mujeres. La reinvención de la naturaleza. Madrid: Cátedra

Homero (1995): Ilíada, edición de Antonio López Eire. Madrid: Cátedra

Huizinga, Johan (1994). Homo ludens. Barcelona: Alianza

Jameson, Fredric (1992); Signatures of the Visible, New York: Routledge

Kant, Immanuel (1991 [1997]): Crítica del juicio. Madrid: Espasa Calpe

Levy, David (2007): Amor + sexo con robots. La evolución de las relaciones entre los humanos y las máquinas. Barcelona: Paidós

Lotman, Yuri (2015), "Las muñecas en el sistema de la cultura", en Muñeca. Madrid: Casimiro, págs. 45-53

Melot, Michel (2010); Breve historia de la imagen. Madrid. Siruela

Mitchell, W. J. T. (1986): Iconology: Image, Text, Ideology. Chicago: University of Chicago Press

Mitchell, W. J. T. (1995); "Representation", en F Lentricchia \&t T McLaughlin (eds), Critical Terms for Literary Study [2ª edición, ampliada], Chicago: University of Chicago Press; págs. 11-22

Mitchell, W. J. T. (2009); Teoría de la imagen. Ensayos sobre la representación verbal y visual, Madrid: Akal

Mitchell, W. J. T. (2011); "¿Qué es una imagen?", en Filosofía de la imagen; Ana García Varas (ed.). Salamanca: Universidad de Salamanca, Salamanca

Ortega y Gasset, José: "La deshumanización del arte" (1925), en La deshumanización del arte y otros ensayos de estética (1987). Madrid: Revista de Occidente-Alianza Editorial, Madrid, págs. 11-54

Panofsky, Erwin (1981); Renacimiento y renacimientos en el arte occidental. Madrid, Alianza Editorial

Panofsky, Erwin (1985); "La historia del arte en cuanto disciplina humanística", en El significado en las artes visuales. Madrid. Alianza

Peirce, Charles Sanders (1958): The Collected Papers of Charles Sanders Peirce. Harvard University Press. Accesible en internet en: https://colorysemiotica.files.wordpress.com/2014/08/peirce-collectedpapers.pd

Popper, Karl R. (1991 [1983]): Conjeturas y refutaciones. El desarrollo del conocimiento científico. Barcelona: Paidós

Serrano, Javier (2018): Un mundo robot. Córdoba: Almuzara

Silver, Anna Krugovoy. "The Cyborg Mystique: 'The Stepford Wives' and Second Wave Feminism." Women's Studies Quarterly, vol. 30, no. 1/2, 2002; págs. 60-76

Stoichiță, Victor I. (2006): Simulacros. El efecto Pigmalión: de Ovidio a Hitchcock. Madrid. Siruela

Vitta, Maurizio (2000): El sistema de las imágenes. Estética de las representaciones cotidianas. Barcelona, Paidós

Wosk, Julie (2015): My Fair Ladies: Female Robots, Androids, and Other Artificial

Eves. New Brunswick, New Jersey y London, Rutgers University Press 